Article

\title{
WetSpass-Based Study of the Effects of Urbanization on the Water Balance Components at Regional and Quadrat Scales in Beijing, China
}

\author{
Yueqiu Zhang, Shiliang Liu * (D), Fangyan Cheng and Zhenyao Shen \\ School of Environment, State Key Laboratory of Water Environment Simulation, Beijing Normal University, \\ Beijing 100875, China; 13324103182@163.com (Y.Z.); 201531180030@mail.bnu.edu.cn (F.C.); \\ z.y.shen@163.com (Z.S.) \\ * Correspondence: shiliangliu@bnu.edu.cn
}

Received: 7 November 2017; Accepted: 19 December 2017; Published: 22 December 2017

\begin{abstract}
China is the largest country in terms of population and its booming urbanization has exerted negative effects on ground-surface hydrological processes at different spatial scales, land-use types, and water balance, such as surface runoff, groundwater recharge, and evapotranspiration. However, it is not yet well understood as to how the modifications of the spatial patterns of landscapes affect the water balance on a regional scale. In this study, the water and energy transfer among soil, plants, and atmosphere (WetSpass) model was applied to evaluate the urbanization effects on the water balance on a regional scale by using Beijing as the case city for this current study. The relationships among impervious surfaces, landscape pattern indices, and water balance components were also quantified. Results indicated built-up land in 2012 was $673 \mathrm{~km}^{2}$ larger than it in 2000, mostly converted from croplands. WetSpass model also indicated the variation rates of annual average surface runoff, evapotranspiration and groundwater recharge were $7 \%, 0.4 \%$ and $-2 \%$ in the whole Beijing area, while they reached $52 \%, 6 \%$ and $-24 \%$ in the urban area of Beijing from 2000 to 2012, respectively. At a city scale, four districts-Dongcheng, Xicheng, Chaoyang, and Haidian-were characterized by higher impervious percentage, as reflected by lower groundwater recharge and higher surface runoff than other districts. At quadrat scale, however, groundwater recharge (surface runoff) was negatively (positively) correlated with impervious percentages. For landscape indices, the Aggregation Index was positively correlated with surface runoff and negatively correlated with groundwater recharge while Patch Density Index, Splitting Index, Patch Richness Density Index, and Shannon's Diversity Index presented opposite relationships. The results of this study can help to develop human knowledge about the impacts of urbanization on hydrological cycles on a regional scale.
\end{abstract}

Keywords: urbanization; water balance; landscape index; hydrological model; Beijing

\section{Introduction}

Due to rapidly increasing population and developing economy, the urban area is expanding rapidly. As a result, the characteristics of urban hydrological cycle are being increasingly modified. Furthermore, the amounts, rates, locations and timing of water balance components, such as surface runoff, groundwater recharge and evapotranspiration, are making different responses worldwide [1]. In the process of urban expansion, the most important change is the increase of impervious surface, which will affect the groundwater level, interception, evaporation and consequently influence runoff, evapotranspiration and basic flow.

Groundwater recharge is vital for water supply of food production, agricultural irrigation and drinking water for most urban areas. Its sources and flow paths can be altered compared with the 
natural conditions due to urbanization, which will cause a series of adverse effects on the surrounding environment [2]. Furthermore, the occurrence of large urban areas can change the runoff coefficient, flow direction, and base flow, and finally influence hydrological balance. In addition, the underlying surface changes due to urbanization will lead to a reduction in vegetation area, and hence decrease interception rate. Therefore, similar precipitation events will produce more ground-surface runoff on impervious surface than vegetated surfaces [3]. In addition, the total evapotranspiration, including vegetation transpiration and soil evaporation, which are complex and affected by land-use types, soil types, precipitation, and other environmental factors, will also decrease or increase because of increased impervious ground surfaces [4]. Therefore, rapid urban expansion has important effects on water balances and influences the management of water resources.

Large-scale urbanization and its effects on hydrological cycles and ecological environment on regional and global scales have been widely discussed in recent years [5,6]. Many have believed that urbanization can trigger a widespread transition from natural landscapes to man-made landscapes and greatly modify the types of land use and land cover and landscape characteristics [7]. Especially, the increases in impervious surfaces make the urban landscape patterns tend to be more fragmented and complex [8,9]. More importantly, changes in landscape patterns due to urban expansion can lead to a series of hydrological effects, such as the alteration of the underlying surface, total runoff volume, and flow characteristics of flood peak [10]. As a result, urban expansion can modify precipitation changes with respect to spatial patterns and precipitation quantities. These disastrous hydrological issues were usually considered as a kind of "urban disease" caused mainly by disturbed water balances and flood risks [11]. Specifically, land-use changes dominated by shifts from vegetated land to impervious surfaces could trigger occurrences of alterations of hydrological processes and hence disastrous hydrological extremes [12].

The hydrological effects of urbanization have been attracting more attention. Previous studies have mainly focused on the impacts of land-use and land-type variations on hydrographic features, such as the storm-water runoffs [13]. Corbett et al. [14] found a linear relationship between impervious surfaces and runoffs. The streamflow characteristics of a highly urbanized watershed in Atlanta area were compared with less urbanized and non-urbanized watersheds by Rose et al. (2001) [15], and the results indicated that the peak flows in the highly urbanized watersheds were $30 \%$ to $100 \%$ greater than those in the less urbanized watersheds. Grischek et al. (1996) [16] found the groundwater recharge in Dresden, Germany decreased by 23\% due to impervious surface. However, many inconsistent results were also found in previous literatures. Kalin and Hantush [17] simulated the effects of land-use changes on hydrological characteristics, pointing out that the base flow would decrease with $31 \%$ magnitude when $60 \%$ of forested lands were translated into built-up lands. Barron et al. (2012) [18] pointed out that the groundwater recharge rates in Perth, Australia, were 2-3 times higher than those in less-urban conditions along with the lower evaporative losses. Therefore, the effects of urbanization on water balance components for different study areas were hard to predict due to human activities and natural factors.

A series of hydrological models have been developed to simulate and quantify the effects of urbanization on the hydrological effects [12]. Physically distributed models, such as MIKE SHE (System Hydrological European), have performed well in ungauged basins [19]. TOPMODEL (Topographic Hydrologic Model) is suitable for determining the areas of runoff in mountainous regions [20]. The SWAT (Soil and Water Assessment Tool) was applied widely to predict the effects of different soil textures, vegetation covers, and land-use on water production, sediment yield and non-point source pollution, which requires large and complicated parameters [21]. For researching the regional water balances, the WetSpass model is definitely the right choice [22]. It takes many influencing factors, such as land-use type, terrain, temperature, precipitation, and wind speed into account, and can quantify the long-term effects of urbanization on the water regime in a watershed. More importantly, it is customizable and adapts easily to new definitions of parameters [23,24]. 
In recent years, how land-use change has affected the hydrological cycle and hydrological components has been studied based on the WetSpass model worldwide. For example, Wang et al. (2012) [25], Gebreyohannes et al. (2013) [22] and Zomlot et al. (2015) [26] evaluated the spatial distribution of water resources, including groundwater recharge and runoff, based on WetSpass model. In addition, Zomlot et al. (2017) [27] assessed the importance of different controlling factors in groundwater recharge. WetSpass and GIS were used to study rainfall infiltration recharge under the influences of different land uses in the Songnen Basin in Northeast China [28]. Dams et al. (2013) [29] evaluated the hydrological dynamics using WetSpass and remote sensing techniques to interpret the impervious surface changes. Poelmans et al. (2010) [12] coupled three urban expansion scenarios with hydrological models and identified the importance of spatial pattern. However, little is known about the changes of specific hydrological components due to urbanization at different scales. Furthermore, applications of the WetSpass model with landscape dynamics assessments of the watersheds with rapid urban expansion are still lacking. In addition, the extent to which the changes in the landscape patterns affect the hydrological cycle has not yet been clarified. The clarifications of these scientific issues are of great scientific and theoretical merit in terms of the hydrological effects of urbanization and hydrological responses to human activities at different spatial and temporal scales.

Beijing, the largest city in China, has undergone remarkably rapid urbanization processes in recent decades. In the process of city development, the types of land use have changed greatly, and the hydrological cycle has experienced significant alterations. Some studies have shown that the groundwater level has declined rapidly in Beijing due to over-exploitation and decreased groundwater recharge [30]. In addition, the agricultural land area has decreased greatly. With rapid urbanization and an increased population, the shortage of water resources has become an important factor affecting the economic development of Beijing. It is therefore necessary to analyze how the water balance has changed due to urban expansion in the past decades at different scales and identify the relationship between landscape pattern and water balance components. The objectives of this study are to address the following scientific issues:

(1) How does urbanization impact the water balance components (groundwater recharge, surface runoff and evapotranspiration) at a city scale and a quadrat scale based on the WetSpass model?

(2) What are the relationships between impervious percentages and water balance?

(3) What are the relationship between landscape indices and groundwater recharge, surface runoff?

Answering these issues will enhance our understanding of the effects of urbanization on water balance and will provide an effective way to evaluate the relationships among impervious surface percentages, landscape index, and water balance.

\section{Data and Methods}

\subsection{Study Area}

Beijing is located in the North China Plain $\left(39^{\circ} 28^{\prime}-41^{\circ} 05^{\prime} \mathrm{N}, 115^{\circ} 25^{\prime}-117^{\circ} 30^{\prime} \mathrm{E}\right)$, covering 14 districts and 2 counties with a total area of $16,410 \mathrm{~km}^{2}$ [31]. The urban area is surrounded by high mountains in the western and northern sides with altitudes of 1000-1500 m. The plains area in Beijing covers $6390.3 \mathrm{~km}^{2}$ in the eastern and southern parts of the Beijing metropolitan region [32]. Beijing has a warm temperate continental monsoon climate and the seasonal distribution of precipitation in this area is not even and the annual average precipitation has been about $600 \mathrm{~mm}$ in recent years, almost $80 \%$ of which is concentrated in summer (from June to September) [33]. The annual average temperature ranges $10{ }^{\circ} \mathrm{C}-12{ }^{\circ} \mathrm{C}$, and the soil texture mainly consists of sand, loamy sand, sandy loam, silty loam, loam, sandy clay loam, clay loam, and clay [34]. In the past three decades, Beijing has been undergoing fast economic development and urban construction, and the urban population increased from 9.0 million to 23.0 million [35]. In addition, the city sprawls out following a share pie development model with a series of concentric ring roads construction. The study area is shown in Figure 1. 


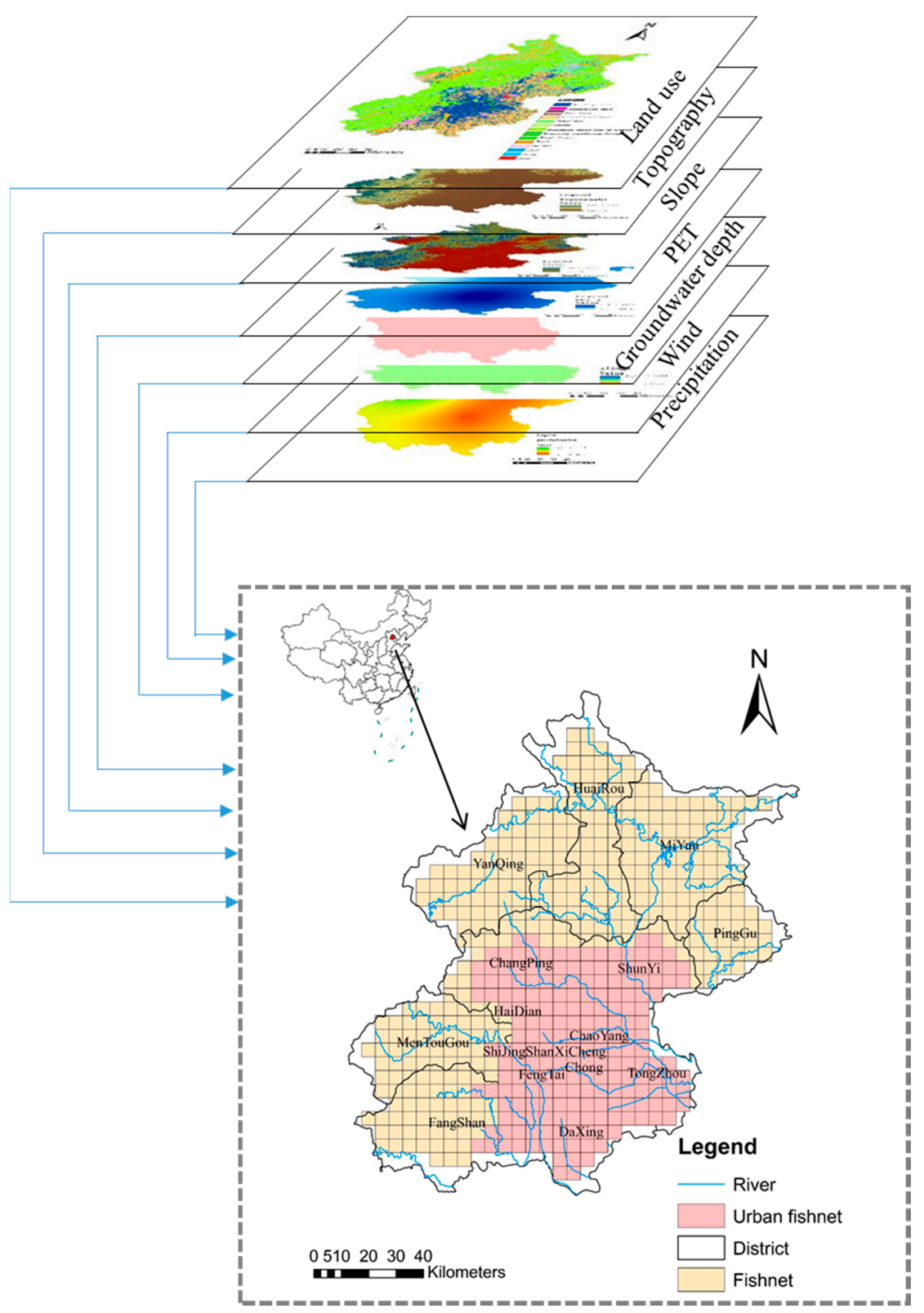

Figure 1. Location of the study area and the quadrat fishnet.

\subsection{Data}

WetSpass requires a combination of ArcView grid files, including land use, precipitation, potential evapotranspiration (PET), wind speed, topography, slope, soil texture, and groundwater depth (Figure 1). Land-use data, including for 2000 and 2012, were initially obtained from two Landsat TM images (Row 33, Path 123), both collected from June to September for the year with accuracy of the Kappa statistics of 0.89 and 0.84 , respectively. A digital elevation model (DEM) with a resolution of $30 \mathrm{~m}$ is available in Global Land Cover Facility (http:/ /gdem.ersdac.jspacesystems.or.jp/). Slope was derived by Spatial Analyst Tools with the GIS. The 1:1,000,000 soil texture data were initially obtained from the soil map provided by China Soil Database at (http:/ / www.soil.csdb.cn/). Monthly data of precipitation and wind speed in 2000 and 2012 were derived from 20 local meteorological stations including Changping, Huairou, Miyun, Yanqing and elsewhere. Potential evapotranspiration (PET) was calculated by the Pennman-Monteinth equation. Twenty-seven groundwater depth data at point 
level were referred to the China Geological Environment Monitoring Groundwater Level Yearbook in 2000 and 2012, and the spatial map of groundwater depth was derived by kriging interpolation.

\subsection{Methods}

\subsubsection{GIS Analysis and Landscape Pattern Index Calculation}

Landsat TM images were digitalized and interpreted to analyze impervious surfaces and landscape changes and their effects on hydrological characteristics. Based on supervised classifications and field survey data with current land-use maps, land-use types in Beijing are subdivided into the following 14 categories: built-up land, industrial land, bare land, agricultural land, grassland, meadow, deciduous broad-leaved forest, coniferous forest, mixed forest, shrub, wetland, lake, river, and road.

To study the relationship between impervious percentages and water balance, the impervious surfaces, mainly consisting of built-up land, industrial land and roads, were extracted. The impervious percentage can be considered as the proportion of those land-use types calculated by combining them together [36].

Urbanization always leads to changes in the landscape patterns. To better understand the relationship between landscape pattern and water balance, we attempted to study the variations of different landscape indices that could reflect landscape fragmentation and diversity information at different levels. Referring to the land-use change, human disturbance, and previous studies, we selected five typical landscape indices to quantify landscape pattern, including Patch Richness Density (PRD), Shannon's Diversity Index (SHDI), Patch Density (PD), Aggregation Index (AI), and Splitting Index (SPLIT) [37]. PRD and SPLIT were employed to quantify the fragmentation information. AI was used to assess the distribution of patch types. SHDI and PRD were used to quantify the structural components of the diversity information [38]. The above five indices, whose ecological meanings and mathematical expressions are shown in Table 1, were calculated by Fragstats 4.2 using the moving window analysis.

Table 1. Selected landscape indices and their ecological meanings.

\begin{tabular}{cccl}
\hline Landscape Indices & Abbreviations & Formulas & Ecological Meanings \\
\hline Patch Density & PD & $P D=N / A$ & $\begin{array}{l}\text { The larger the PD value, the more severe } \\
\text { the degree of fragmentation. }\end{array}$ \\
\hline Splitting Index & SPLIT & $S P L I T=\frac{A^{2}}{\sum_{i=1}^{m} \sum_{j=1}^{n} a_{i j}^{2}}$ & $\begin{array}{l}\text { The SPLIT value reflects the subdivision } \\
\text { degree of a landscape. }\end{array}$ \\
\hline Patch Richness Density & PRD & PRD $=\mathrm{m} / \mathrm{A}$ & $\begin{array}{l}\text { The PRD is larger if there are more } \\
\text { patch types. }\end{array}$ \\
\hline Shannon's Diversity Index & SHDI & $S H D I=-\sum_{i=1}^{m}\left(P_{i} \times \ln P_{i}\right)$ & $\begin{array}{l}\text { SHDI implies the abundance and } \\
\text { distribution of different landscape types. }\end{array}$ \\
\hline Aggregation Index & AI & $A I=\left(\sum_{i=1}^{m}\left(\frac{g_{i i}}{m a x-g_{i i}}\right) P_{i}\right)$ & $\begin{array}{l}\text { AI increases with the more concentrated } \\
\text { patch types. }\end{array}$ \\
\hline
\end{tabular}

Note: $N=$ total number of patches in the landscape; $A=$ total landscape area; $a_{i j}=$ area of patch $i j ; m=$ number of patch types (classes) in the landscape; $P_{i}=$ proportion of the landscape occupied by patch type (class) $i ; g_{i i}=$ number of like adjacencies (joins) between pixels of patch type (class) $I$; max- $g_{i i}=$ maximum number of like adjacencies (joins) between pixels of patch type (class) $i$.

The research was conducted at city scale and quadrat scale, respectively. At quadrat scale, the continuous quadrats of $5 \mathrm{~km} \times 5 \mathrm{~km}$ were delineated by ArcGIS to identify the correlations between impervious surface landscape patterns, and water balance at the quadrat scale. Totally, there are $5695 \mathrm{~km} \times 5 \mathrm{~km}$ quadrats in the whole study area and only 201 quadrats in urban area of Beijing. The fishnet map is shown in Figure 1. In each quadrat, the average value of impervious percentages and different landscape pattern indices were calculated by zonal statistics in ArcGIS. 


\subsubsection{The WetSpass Model}

WetSpass is a physically based, spatially distributed water balance model and can be used to simulate long-term annual and seasonal average surface runoff. Groundwater recharge and actual evapotranspiration on a regional scale can also be derived [39,40]. Inputs for this model contain several grid maps. Pre-defined parameters in the WetSpass model, including land use, soil types, and runoff coefficient, are connected to the model as attribute tables of their respective grids. The water balance is calculated for summer from April to September and winter from October to March. The results are consequently summed to obtain the annual values.

In this study, the grid size of raster data is $90 \mathrm{~m} \times 90 \mathrm{~m}$ and the water balance computation is performed at a raster cell level. Water balance at each raster is obtained by summing the independent water balances for the vegetated, bare soil, open-water, and impervious fraction. The total water balance of a given area is thus calculated as the summation of the water balance of each raster cell. Taking the vegetated area as an example, the water balance can be calculated per grid according to Equations (1)-(3):

$$
\begin{gathered}
P=I+S_{v}+E T_{v}+R_{v} \\
E T_{v}=T_{v}+E_{s} \\
E T_{\text {tot }}=I+T_{v}+E_{s}
\end{gathered}
$$

where $P$ is the average annual precipitation ( $\mathrm{mm} /$ year). $I$ is the interception ( $\mathrm{mm} /$ year) and depends on the vegetation types. $S_{v}$ is the surface runoff ( $\mathrm{mm} /$ year) related to precipitation amount, precipitation intensity, interception, and soil infiltration capacity. $E T_{v}$ is the actual evapotranspiration (mm/year). $R_{v}$ is the groundwater recharge ( $\mathrm{mm} /$ year) calculated as a residual term of the water balance. The actual evapotranspiration, $E T_{v}\left(\mathrm{~mm} /\right.$ year), is the sum of $T_{v}$ and $E_{S}$. The total actual evapotranspiration, $E T_{\text {tot }}$ $\mathrm{mm} /$ year), is the sum of intersection $(I)$, transpiration $\left(T_{v}\right)$ and the evaporation, $E_{\mathrm{s}}(\mathrm{mm} /$ year) from the bare soil. A similar procedure as that for the vegetated surfaces is followed for the calculation of bare-soil, open-water, and impervious surfaces. The only difference is that there is no vegetation in these cases and thus there is no interception and transpiration. A more detailed description, calibration, and validation of the WetSpass model can be found in Batelaan and Smedt (2007) [41].

\subsubsection{Water Fluctuation Method}

The correct calibration of a model can greatly improve its performance and hence the modelling results. To validate the performance of the optimized model after calibration, the water fluctuation method, which is widely applied to calculate the groundwater recharge, was also available to the calibration and validation of WetSpass model. The calculation formula is as Equation (4):

$$
R_{\text {year }}=\mu \times \sum \Delta h
$$

$R_{\text {year }}$ is the yearly groundwater recharge (mm); $\mu$ represents the specific yield which is mostly relevant to lithology (Table 2); and $\sum \Delta h$ is the total variation amplitude of groundwater caused by precipitation.

Table 2. The empirical values of specific yield for different lithologies.

\begin{tabular}{cccc}
\hline Lithology & $\mu$ & Lithology & $\mu$ \\
\hline Clay & $0.02-0.035$ & Medium sands & $0.09-0.13$ \\
Loam & $0.02-0.05$ & Medium coarse sand & $0.10-0.15$ \\
Sandy loam & $0.03-0.06$ & Coarse sand & $0.11-0.15$ \\
Silty sand & $0.06-0.1$ & Sandstone & $0.02-0.03$ \\
Fine sand & $0.08-0.12$ & Limestone & $0.008-0.10$ \\
\hline
\end{tabular}




\section{Results}

\subsection{The Impacts of Urban Expansion on Landscape Pattern}

The comparison of two periods for land uses is shown in Figure 2. Overall, forests were widely distributed in the north and southwest parts and agricultural lands were relatively scattered. Grassland is mainly alpine meadow and distributed in the mountainous area. The proportion of bare land is very small and scattered. Built-up lands are in the center and southern part. Moreover, the built-ups areas increased and decentralized from 2000 to 2012. The transformed areas for each land-use type between 2000 and 2012 are presented in Figure 3.
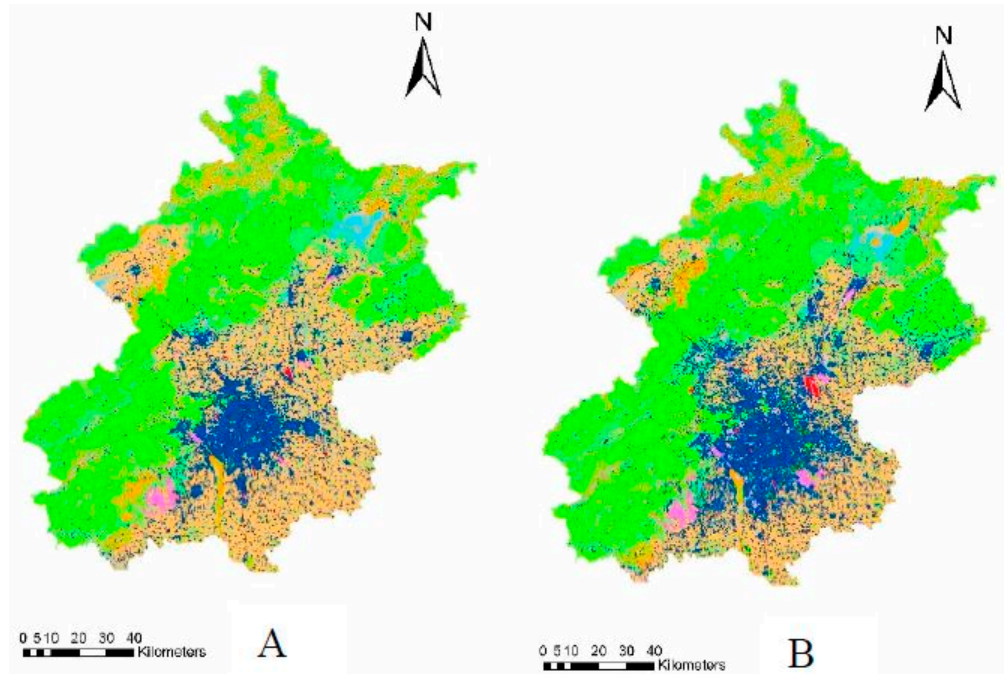

\begin{tabular}{l} 
Landuse types \\
Built-up land \\
Industrial land \\
Bare land \\
Agricultural land \\
Grassland \\
Meadow \\
Deciduous broad-leaved forest \\
Evergreen coniferous forest \\
Mixed forest \\
Shrub \\
Wetland \\
\hline Lake \\
River \\
Road
\end{tabular}

Figure 2. The land uses in: 2000 (A); and 2012 (B).

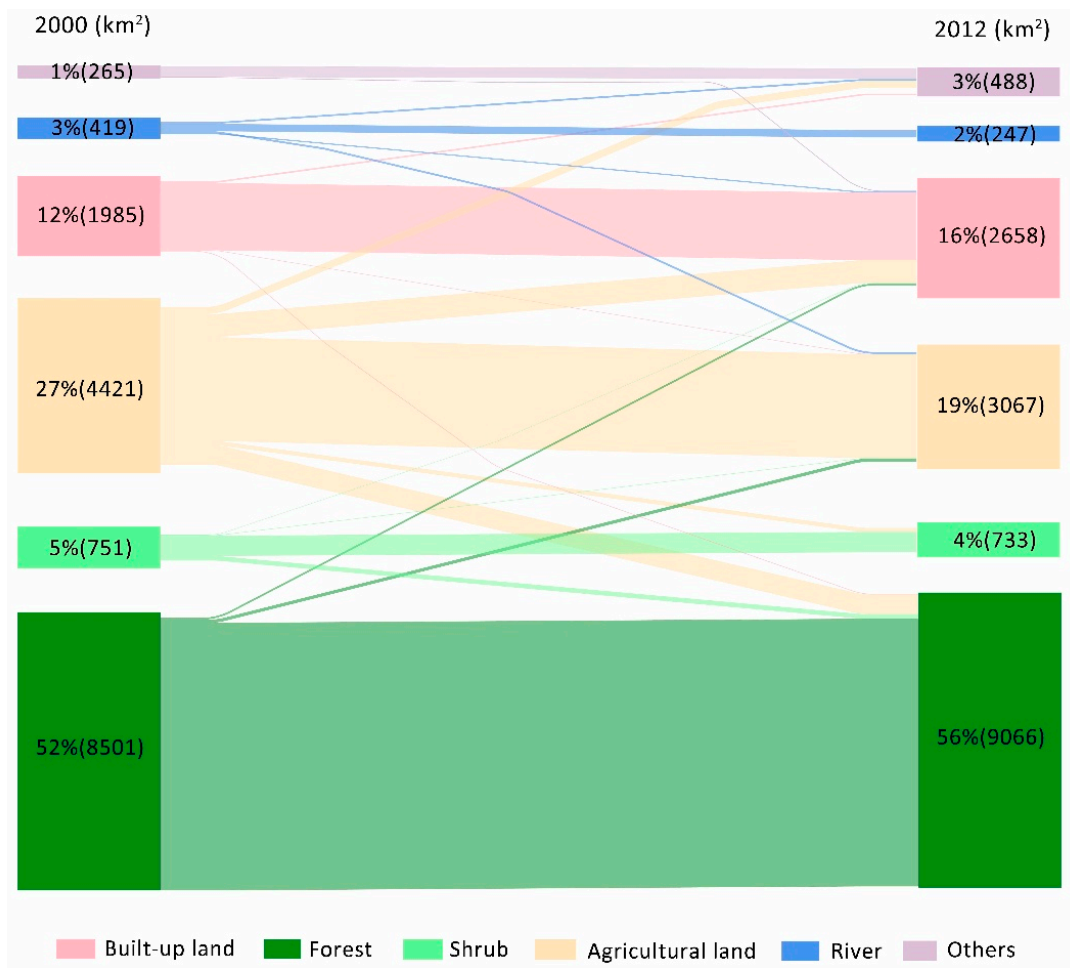

Figure 3. Area change of different land-use types from 2000 to 2012. 
As shown in Figure 3, forest is the largest land-use type in the area and composed of deciduous broad-leaved forest, evergreen coniferous forest, and mixed forest. In the past 13 years, the area of forests increased. In addition, agricultural land occupies a large area. From 2000 to 2012, the area of agricultural land declined greatly from $27 \%$ to $19 \%$ which was mostly converted into built-up land and mixed forest. City expansion resulted in the increase of built-up land and the amount in total reached $673 \mathrm{~km}^{2}$ from 2000 to 2012. Specifically, $743 \mathrm{~km}^{2}$ of built-up lands were translated from agricultural land $\left(641 \mathrm{~km}^{2}\right)$, forest $\left(49 \mathrm{~km}^{2}\right)$ and all other land use types $\left(53 \mathrm{~km}^{2}\right)$, while total area of $80 \mathrm{~km}^{2}$ for built-up lands were translated into agricultural land, grassland, forests, and roads.

From 2000 to 2012, the landscape indices were relatively stable but slightly increased as a whole (Table 3). PD was 0.28 higher in 2012 than 2000, which indicated that the degree of fragmentation increased due to urbanization and the result of SPLIT was consistent with PD. In addition, the larger AI value in 2012 showed the heterogeneity of the landscape increased. SHDI explaining the diversity of landscape increased when PRD increased, which suggested that the patches were more scattered.

Table 3. The landscape index of 2000 and 2012.

\begin{tabular}{ccc}
\hline Landscape Index & $\mathbf{2 0 0 0}$ & $\mathbf{2 0 1 2}$ \\
\hline Patch density & 13.23 & 13.51 \\
Splitting index & 1.77 & 1.82 \\
Aggregation index & 87.63 & 87.52 \\
Patch richness density & 10.63 & 10.87 \\
Shannon's Diversity Index & 0.50 & 0.54 \\
\hline
\end{tabular}

\subsection{Simulation of Hydrological Distribution Based on WetSpass Model}

\subsubsection{The Calibration and Validation of WetSpass Model}

In our simulation, three of the most sensitive input data were land-use parameter, soil parameter, and runoff coefficients. To obtain a best fit between observed and simulated water balance components, we constantly adjusted those parameters, combining actual investigation and related research $[42,43]$.

As for land-use types, we should consider the runoff vegetation in the underlying surface, including grass, forest, crop, open water, and bare soil that were catalogued into vegetation, impervious area, open water, and bare land for each class according to the model's requirements (Table A1). In addition, the soil parameters consisted of field capacity, wilting point, plant available water content, residual water content, bare soil evapotranspiration depth, tension saturated height, and fraction of precipitation for summer and winter (Table A2). The accurate runoff coefficients for different land-use types, slopes, and soil types were crucial to the simulation of water balance components. In general, a higher slope would lead to higher runoff coefficients. With the same land-use type and slope, sand soil had the lowest runoff coefficient and clay soil had the highest. The specific parameters for land use, slope, and soil types are shown in Table A3.

The observed data were obtained from China Groundwater Level Yearbook for Geo-Environmental Monitoring (2012), which recorded the detailed yearly groundwater levels from about 50 monitoring points in Beijing [44]. Among them, 23 monitoring points cannot be accurately positioned in Google Earth. To ensure the authenticity and accuracy of model verification, we chose the groundwater levels of 27 monitoring points to calculate the groundwater recharge as shown in Table A4. Furthermore, the simulated groundwater recharge at corresponding positions in 2012 were extracted by ArcGIS. Figure 4 displays the simulated and measured groundwater recharges, which showed a good linear relationship with an $R^{2}$ of 0.82 . Thus, we assumed that the water balance components simulated by the WetSpass model in 2000 and 2012 are still reasonable. 

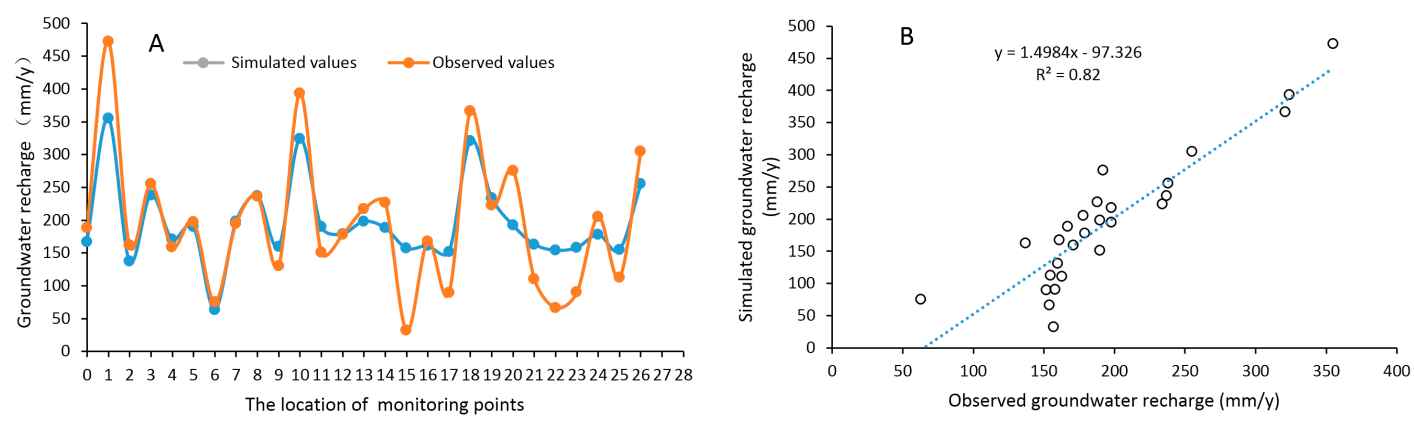

Figure 4. Evaluation of simulated and measured groundwater recharge: (A) the simulated values and observed values of groundwater recharge in 2012 for 27 monitoring points; and (B) the linear relationship between simulated and observed groundwater recharge.

\subsubsection{The Water Balance Components of 2000 and 2012}

Tables 4 and 5 show the seasonal and annual water balance components in the whole area of Beijing and only the urban region in Beijing for two periods. It is clear that the changing trends for each seasonal and annual water balance component were similar while the absolute values were different. Surface runoff and evapotranspiration both presented increasing trends while groundwater recharge decreased from 2000 to 2012. The annual average amount of precipitation was approximately $890 \mathrm{~mm}$ with $571 \mathrm{~mm}$ evapotranspiration, $277 \mathrm{~mm}$ recharge, and $43 \mathrm{~mm}$ runoff in 2000, while $573 \mathrm{~mm}$ evapotranspiration, $272 \mathrm{~mm}$ recharge, and $46 \mathrm{~mm}$ runoff in 2012.

Table 4. Seasonal and annual water balance components in the whole Beijing area from 2000 to 2012 (mm).

\begin{tabular}{cccccccccccc}
\hline \multirow{2}{*}{ Parameter } & \multirow{2}{*}{ Value } & \multicolumn{3}{c}{ Runoff } & \multicolumn{4}{c}{ Evapotranspiration } & \multicolumn{3}{c}{ Recharge } \\
\cline { 3 - 11 } & & Year & Winter & Summer & Year & Winter & Summer & Year & Winter & Summer \\
\hline \multirow{3}{*}{2000} & Range & $0-525$ & $0-115$ & $0-440$ & $368-652$ & $43-152$ & $287-500$ & $0-430$ & $0-85$ & $0-403$ \\
& Ave. & 43 & 14 & 29 & 571 & 102 & 471 & 277 & 42 & 233 \\
& SD & 61 & 27 & 42 & 28 & 17 & 27 & 67 & 20 & 54 \\
\hline \multirow{2}{*}{2012} & Range & $0-525$ & $0-115$ & $0-440$ & $368-652$ & $43-152$ & $287-500$ & $0-428$ & $0-85$ & $0-401$ \\
& Ave. & 46 & 16 & 30 & 573 & 100 & 475 & 272 & 42 & 232 \\
& SD & 60 & 29 & 37 & 27 & 17 & 25 & 62 & 19 & 49 \\
\hline \multicolumn{2}{c}{ Variation $\left._{\text {Ave }_{2012}-\text { Ave }_{2000}}^{\text {Ave }_{2000}}\right)$} & $+7 \%$ & $+14.3 \%$ & $+3 \%$ & $+0.4 \%$ & $+2 \%$ & $+8 \%$ & $-2 \%$ & 0 & $-0.4 \%$ \\
\hline
\end{tabular}

Table 5. Seasonal and annual water balance components in urban region of Beijing from 2000 to 2012.

\begin{tabular}{|c|c|c|c|c|c|c|c|c|c|c|}
\hline \multirow{2}{*}{ Parameter } & \multirow{2}{*}{ Value } & \multicolumn{3}{|c|}{ Runoff } & \multicolumn{3}{|c|}{ Evapotranspiration } & \multicolumn{3}{|c|}{ Recharge } \\
\hline & & Year & Winter & Summer & Year & Winter & Summer & Year & Winter & Summer \\
\hline \multirow{3}{*}{2000} & Range & $0-477$ & $0-108$ & $0-400$ & $405-652$ & $44-152$ & $325-500$ & $0-413$ & $0-77$ & $0-378$ \\
\hline & Ave. & 57 & 16 & 41 & 582 & 103 & 479 & 250 & 30 & 220 \\
\hline & SD & 67 & 34 & 43 & 26 & 21 & 31 & 81 & 19 & 66 \\
\hline \multirow{3}{*}{2012} & Range & $0-439$ & $0-110$ & $0-369$ & $444-652$ & $44-152$ & $340-500$ & $0-412$ & $0-77$ & $0-378$ \\
\hline & Ave. & 87 & 29 & 57 & 619 & 114 & 505 & 189 & 18 & 171 \\
\hline & SD & 67 & 35 & 39 & 25 & 21 & 30 & 74 & 17 & 59 \\
\hline \multicolumn{2}{|c|}{$\begin{array}{c}\text { Variation } \\
\left(\frac{A v e_{2012}-A v e_{2000}}{A v e_{2000}}\right)\end{array}$} & $+52 \%$ & $+81 \%$ & $+39 \%$ & $+6 \%$ & $+10 \%$ & $+5 \%$ & $-24 \%$ & $-40 \%$ & $-22 \%$ \\
\hline
\end{tabular}

In the whole Beijing region, the annual average surface runoff had the maximum variation rate, which reached $7 \%$, while the variation rates for annual average evapotranspiration and groundwater recharge were less than $2 \%$ from 2000 to 2012. For different seasons, the amounts of water balance components in summer occupied a larger proportion than those in winter. However, the surface runoff 
in winter varied greatly with increasing rate of $14.3 \%$ while the variation rate of evapotranspiration in summer increased by $8 \%$.

In urban region in Beijing, the changing trends for water balance components were similar with those in the whole area. However, the variation rates from 2000 to 2012 were greatly different. The annual average surface runoff and evapotranspiration increased by $52 \%$ and $6 \%$, respectively, while the annual average groundwater recharge decreased by $24 \%$. In different seasons, the amounts and variation rates of surface runoff and evapotranspiration in urban region were both higher than those in the whole area while the groundwater recharge had the opposite state. The surface runoff increased by $81 \%$ and $39 \%$, evapotranspiration increased by $10 \%$ and $5 \%$ while groundwater recharge decreased by $40 \%$ and $22 \%$ in winter and summer from 2000 to 2012 , respectively.

\subsection{Impacts of Urbanization on Water Balance Components}

\subsubsection{The Water Balance at Urban Scale}

Spatially, the annual average runoff, groundwater recharge, and evapotranspiration indicated large heterogeneity for both 2000 and 2012. The range of higher surface runoff increased and the total evapotranspiration did not change greatly, as the groundwater recharge declined obviously according to the overlay of the layers in two periods. Furthermore, we found that the water balance is subject to a similar spatial pattern with that of districts, as shown in Figure 5.

Since the 1980s, the urban areas of Beijing have gradually expanded from the city center to nearby areas. The built-up area reached $1984 \mathrm{~km}^{2}$ in 2000 and $2654 \mathrm{~km}^{2}$ in 2012, according to the land-use reclassification of TM images and is mainly concentrated in Haidian, Chaoyang, Dongcheng, Xicheng, and other districts. Across the entire Beijing region, districts, including Xicheng, Dongcheng, Chaoyang, and Haidian, are characterized by lower groundwater recharge and higher surface runoff. However, suburban and rural areas are the opposite case, with Huairou, Yanqing, Fangshan, and Mentougou having higher groundwater recharge and lower surface runoff. From 2000 to 2012, Beijing underwent tremendous change in the land-use configuration as more districts were developed, especially Changping, Shunyi, and Tongzhou. Water balance varied due to urban expansion. We observed that areas of low groundwater recharge (red color) were scattered and had decreased, while the surface runoff increased considerably in 2012.

The variation in land-use types from 2000 to 2012 were considered as the main influencing factor to spatial differences of water balance components. To assess these influences, we compared the average annual recharge, surface runoff, and actual evapotranspiration for different land use types. The relationships between land use types and water balance components were relatively steady and existed little difference in the same area with short time interval. Figure 6 presents the water balance components as a result of different land cover types in 2000. Overall, the "high-low" sequence of recharge is bare land, grassland, shrub, agricultural land, and built-up land, successively. Furthermore, built-up land has the lowest groundwater recharge, except rivers and lakes, as the recharge from precipitation is very insignificant, and it has a relatively high surface runoff due to the ground with less roughness and higher impervious rates. As for forests, grasslands, and shrubs, they are characterized by a higher evapotranspiration and recharge when the runoff is reduced. In addition, the agricultural land and bare land have more ground-level low roughness ground-level, which leads to increased runoff and decreased evapotranspiration compared with built-up land. Therefore, land use types are considered as an important influencing factor in the dynamic of surface runoff, groundwater recharge, and actual evapotranspiration. 

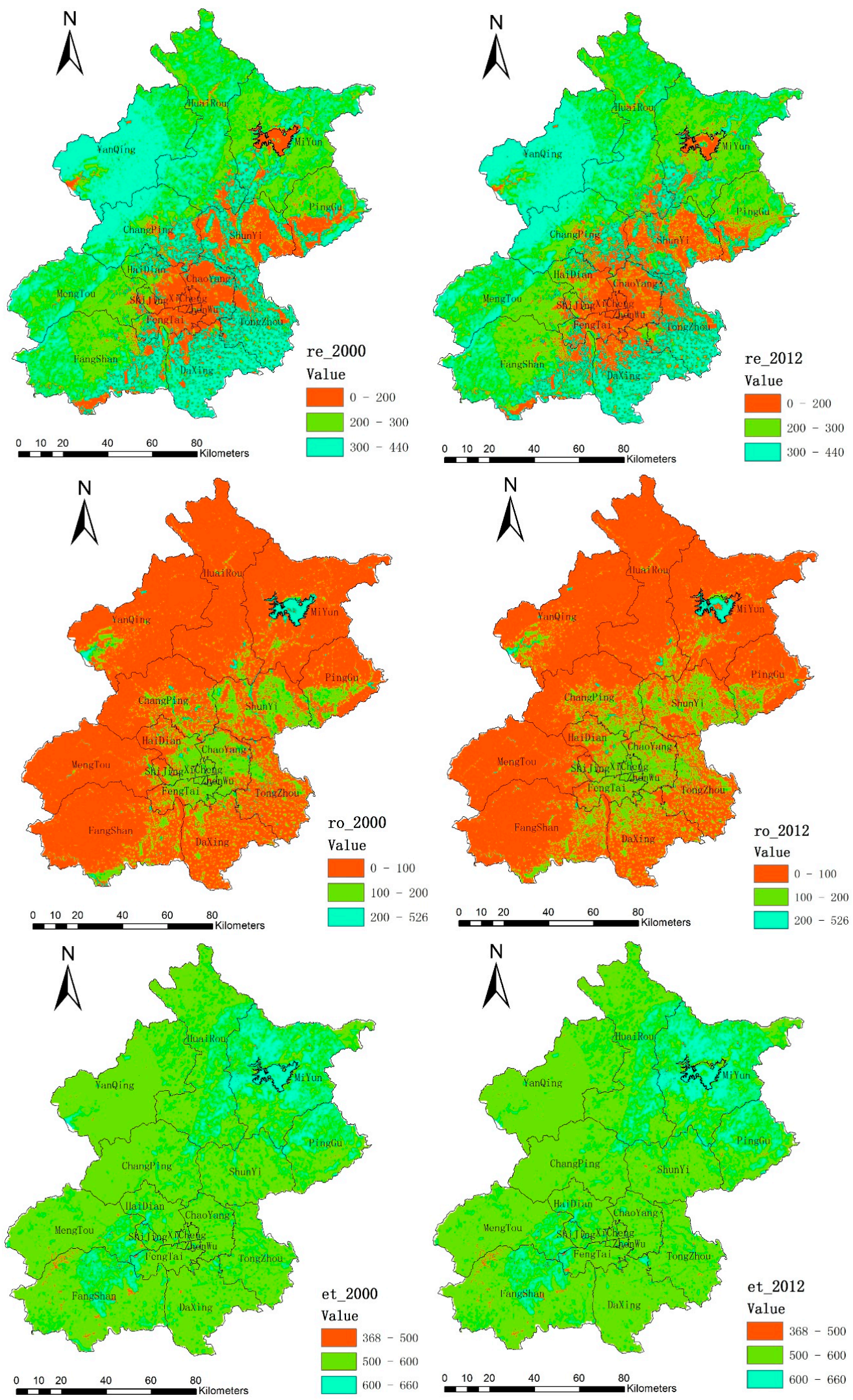

Figure 5. The water balance of 2000 and 2012 (re_2000, ro_2000 and et_2000 are groundwater recharge, surface runoff, and actual evapotranspiration for 2000, respectively; and re_2012, ro_2012 and et_2012 are groundwater recharge, surface runoff, and actual evapotranspiration for 2012, respectively). 


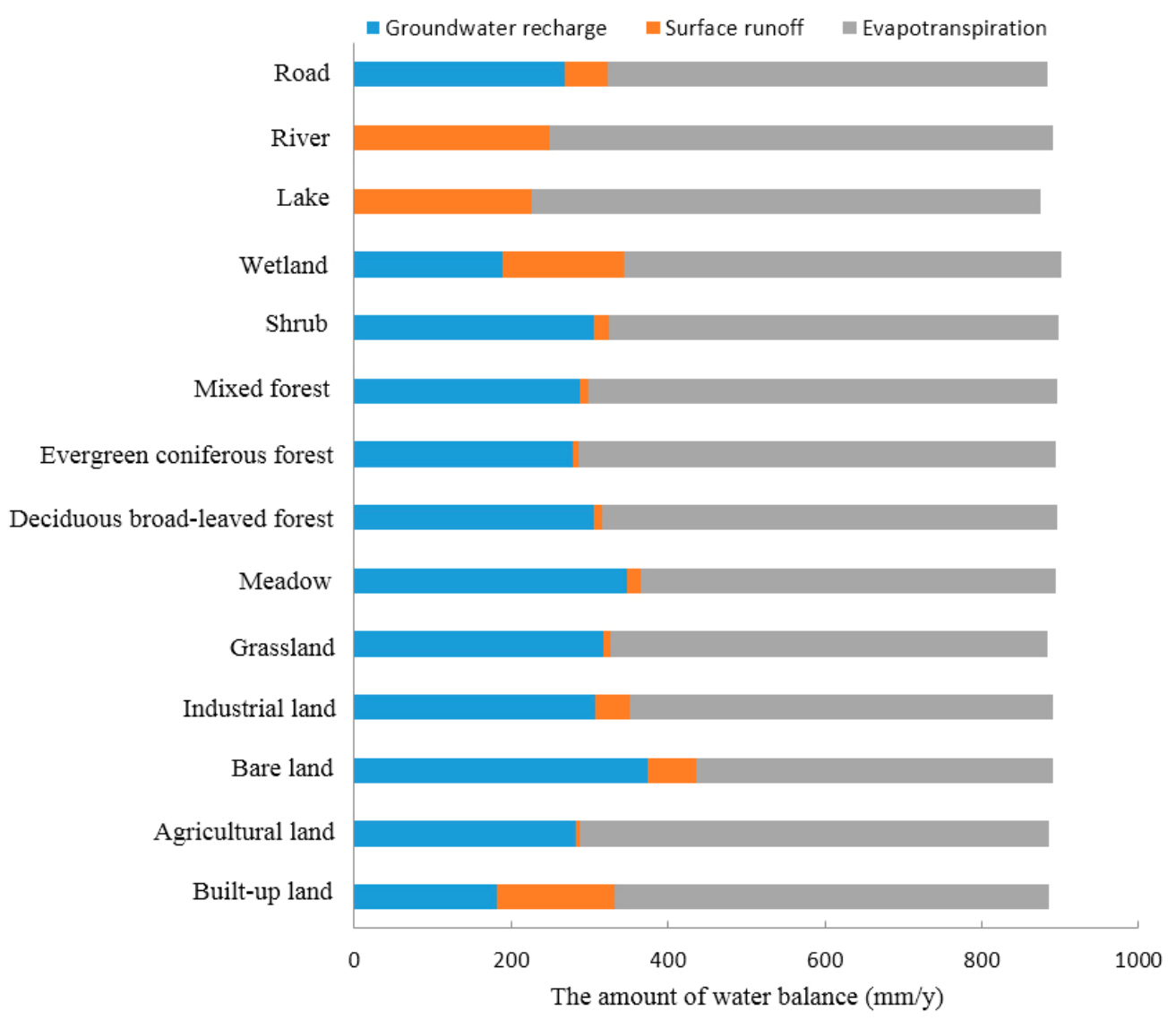

Figure 6. Average annual groundwater recharge, runoff and evapotranspiration for different land-use types.

3.3.2. The Impacts of Impervious Surface Percentages on Water Balance Components at Quadrat Scale

Urbanization level can be expressed as the impervious percentages to a certain extent. Higher impervious percentages imply larger areas of built-up land. On an urban scale, the impervious rate was $13.2 \%$ in 2000 and $16.3 \%$ in 2012. As the difference is relatively small to explain effectively the impacts on water balance on a regional scale, we analyzed the relationship between impervious percentages and water balance components at $5 \mathrm{~km} \times 5 \mathrm{~km}$ quadrat scale. The impervious percentages in 569 quadrats can be assumed as an indicator of urban expansion because each quadrat has a consistent area and the water distribution can be compared. The simple linear regression models between the impervious percentages and water balance components in 2000 and 2012 are shown in Figure 7.

The results indicated that there was a significantly negative correlation between impervious percentages and groundwater recharge. The correlation coefficient, $R^{2}$, was 0.58 in 2000 and 0.65 in 2012, implying that the increased impervious percentages would lead to lower groundwater recharge. On the contrary, the impervious percentages positively correlated with surface runoff and the correlations were significant with the coefficients, with $R^{2}$ reaching 0.61 in 2000 and 0.65 in 2012, as shown in Figure 7A.

By comparison between 2000 and 2012, we found that 352 quadrats had higher impervious percentages in 2012 than 2000 due to urbanization in the whole area of Beijing. Among them, 336 quadrats had higher surface runoff, while 395 quadrats existed with a lower groundwater recharge in 2012 than 2000. However, in terms of evapotranspiration, it does not fit a linear relationship in the whole Beijing area. The main reason is we thought it might be attributed to the scale issue at the quadrat scale and there might be a threshold for the correlation when the whole study extent was taken into account. In our study, the cell size of land use types in 2000 and 2012 was $90 \mathrm{~m} \times 90 \mathrm{~m}$ 
and the cell size of the water balance study was $500 \mathrm{~m} \times 500 \mathrm{~m}$ at quadrat scale. This resolution was suitable to characterize the urbanization in the whole Beijing area, while they may cause some errors for the relationship between imperious percentage and landscape configuration. Some research on urban ecology also verified that landscape configuration could affect heat island, evaporation and evapotranspiration.

To further understand the effects of urbanization on water balance components at quadrat scale, we extracted 201 quadrats in urban region in Beijing. We found surface runoff had significantly positive correlations while groundwater recharge had significantly negative correlations with impervious surface percentages both in 2000 and 2012. In addition, there existed positive, significant relationships between impervious surface percentage and evapotranspiration with correlation coefficient of 0.567 in $2000(p<0.01)$ and 0.510 in $2012(p<0.01)$, as shown in Figure 7B and Table 6.
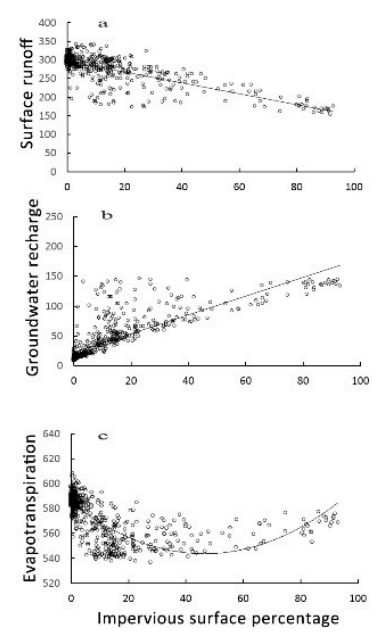

(A)
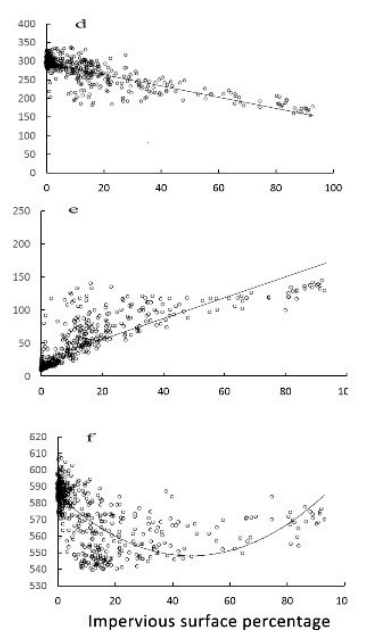

Impervious surface percentage
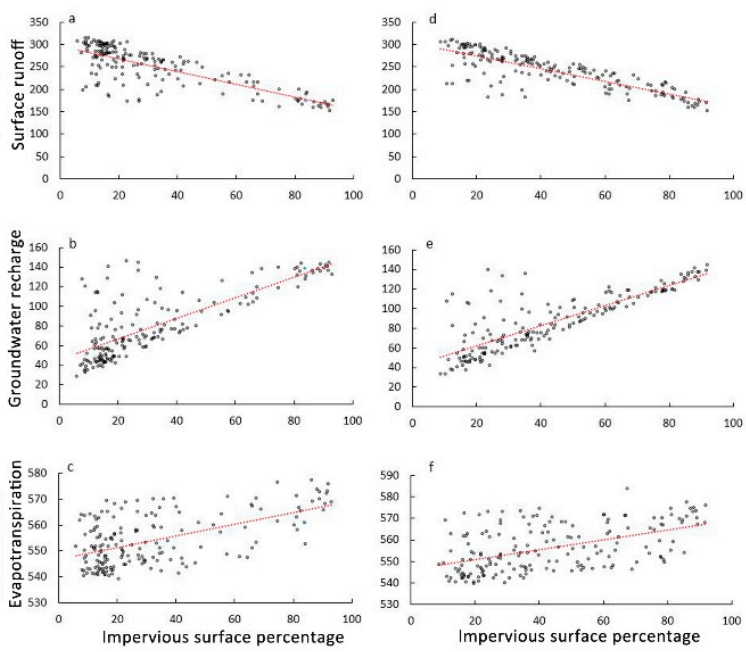

(B)

Figure 7. The correlations of groundwater recharge, surface runoff, and evapotranspiration with impervious percentages: in the whole Beijing area (A); and in urban region of Beijing (B) ((a-c) 2000; and (d-f) 2012).

Table 6. Correlations between the impervious percentages and water balance components in urban region of Beijing in 2000 and 2012.

\begin{tabular}{ccccc}
\hline Independent & Time & Dependent & Correlation model & R \\
\hline \multirow{3}{*}{2000} & Groundwater recharge & $\mathrm{Y}=-1.4241 x+296.28$ & $-0.769^{* *}$ \\
Impervious percentages & Surface runoff & $\mathrm{Y}=1.0454 x+45.985$ & $-0.783^{* *}$ \\
\cline { 2 - 5 } & & Evapotranspiration & $\mathrm{Y}=0.2261 x+546.8$ & $0.567^{* *}$ \\
\cline { 2 - 5 } & \multirow{2}{*}{2012} & Groundwater recharge & $\mathrm{Y}=-1.4205 x+303.52$ & $-0.834^{* *}$ \\
& & Surface runoff & $\mathrm{Y}=1.0241 x+41.671$ & $0.829^{* *}$ \\
& & Evapotranspiration & $\mathrm{Y}=0.2307 x+546.09$ & $0.510^{* *}$ \\
\hline
\end{tabular}

Note: * significant at 0.05 level; ${ }^{* *}$ significant at 0.01 level.

\subsection{Relationship between Landscape Pattern Indices and Water Balance Components}

In 2000 and 2012, the selected five landscape indices showed prominent correlations with groundwater recharge and surface runoff and the correlations decreased from 2000 to 2012. This can be seen in Figure 8. Specifically, AI has a remarkable positive correlation with surface runoff and a negative correlation with groundwater recharge, while the four other indices showed negative correlations with surface runoff and positive correlations with groundwater recharge. AI, SPLIT, and PD all reflect the scattered degree of the landscape. A decreased AI, and increased SPLIT and PD would result in decreased surface runoff and increased groundwater recharge. PRD and SHDI 
revealed the landscape diversity, and increased PRD and SHDI should lead to decreased surface runoff and increased groundwater recharge.
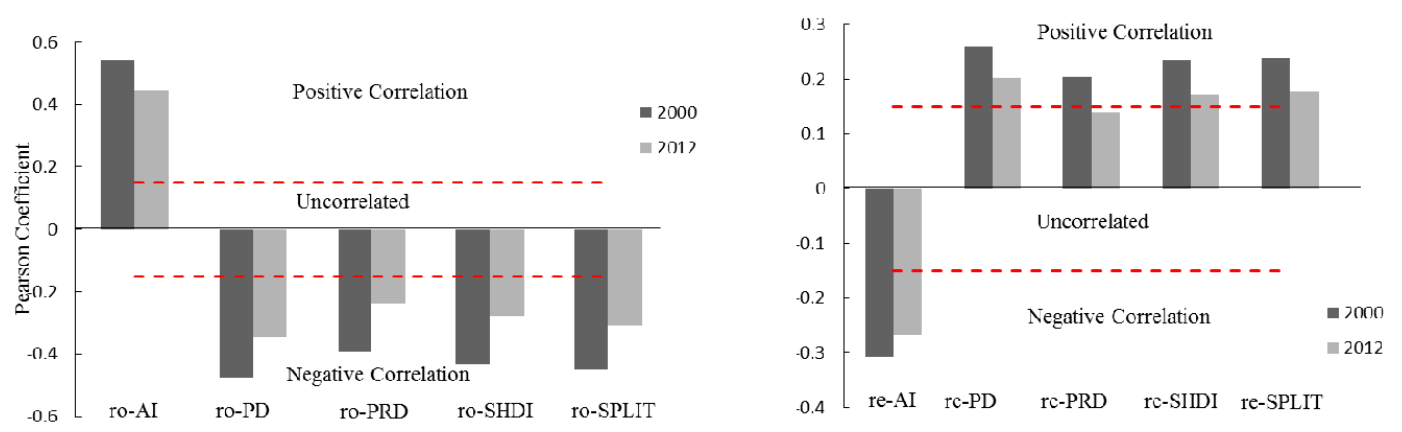

Figure 8. The correlations between landscape index and groundwater recharge (re) and surface runoff (ro) (re-AI represents the correlation between groundwater recharge and AI; and ro-AI represents the correlation between surface runoff and $\mathrm{AI}$ ).

\section{Discussion}

\subsection{The Impacts of Urbanization on Water Balance}

Land use will change during the process of urbanization and then disturb the natural water cycle. However, the water cycle processes are difficult to estimate accurately and therefore there are many methods available such as the hydrology model method [45], remote sensing, the ArcGIS analysis method [46] and others. In our study, we used the WetSpass model to evaluate the changes of water balance components in the last 13 years, and comprehensively considered the influencing factors such as land-use types, topography, precipitation, and soil in this study. Each land-use type was a potential influencing factor behind the state of water bodies from hydrological pollution to distribution of water balance components [47]. Thus, studying the change of land-use types is important for explaining the effects of urbanization.

From 2000 to 2012, the built-up land increased $673 \mathrm{~km}^{2}$ in Beijing, mostly converted from croplands. The result is consistent with Zhu et al. [48] as these researchers pointed out that the area of built-up land was three times higher in 1995 than 1982, after being converted from agricultural land and forests. Impervious surfaces such as built-up lands and other roads are the driving factor of hydrological changes because of urbanization [49].

It will be significant to quantify the water balance components responding to different land-use types, especially in built-up lands. Zomlot et al. [26] displayed how the built-up land had a lower groundwater recharge because of partially impervious surfaces, but the water distribution differed slightly in the average yearly evapotranspiration, groundwater recharge, and surface runoff at $450 \mathrm{~mm}$, $235 \mathrm{~mm}$, and $73 \mathrm{~mm}$, respectively.

At the urban scale, districts, including Xicheng, Dongcheng, Chaoyang, and Haidian, are characterized by lower groundwater recharge $(0-200 \mathrm{~mm} /$ year $)$ and higher surface runoff (100-200 mm/year) than the suburban region including Huairou, Yanqing, Fangshan, and Mentougou (groundwater recharge of 200-400 mm/year and surface runoff of 0-100 mm/year). This is due to the gathered large-area land of built-up, traffic roads, and industrial land. The suburban area and country have an opposite case with wider natural land areas and fewer build up areas than urban locations. Pan et al. [34] and Zhu et al. [48] pointed that increased built-up lands in four districts of the city led to the variations of surface environment of the soil, which enlarged the areas of impervious surfaces.

However, no reports are available to address the impacts of urbanization on water balance on a quadrat scale. There was a significantly negative correlation between impervious percentages and groundwater recharge, and a positive correlation between impervious percentages and runoff both in 2000 and in 2012. Our results indicate that the correlation coefficient increased over time, which implied 
that the increased impervious percentages would play a more important role in water distribution due to urbanization in Beijing.

In the process of urbanization, it is true the precipitation or drought at different scales, even the extreme weather, can affect the water balance at different scales components greatly. Therefore, it is better to consider the effects of climate change on hydrology. Globally, some previous studies distinguished the effects of climate change and urbanization on watershed hydrology [50-53]. It is noted that the climate change should be considered at a relatively longer time scale. In our study, the study period is from 2000 to 2012. In this period, the urban expansion in Beijing was very rapid and obvious. Comparatively, the variations of average annual precipitation are not distinct in the past decades although there could be extreme weather in some years (http:/ / data.cma.cn/data/cdcindex).

In Beijing, many studies explored the relationships between rainfall storm flow and runoff to provide support for scientific decision to solve water management [54]. In addition, some studies in Beijing showed the effects of climate change and urbanization on groundwater recharge [55]. Studies indicated landscape pattern change, due to anthropogenic activities in the process of urbanization, played a major role to groundwater recharge [1,48]. In our study, we also attempted to establish the relationship between landscape pattern changes due to urbanization and the water balance components. Thus, we used the WetSpass which is a quasi-steady state spatially distributed water balance model to exhibit the relationship at different scales. Therefore, in this study, the precipitation dynamics was not the focus and we used the similar precipitation scenarios in two periods to analyze the effects of urbanization on water balance components as our study is a medium time scale research. In our future study, the process-based model WetSpa extension will be used considering the climate change and landscape variations as the influencing factors.

In addition, it is equally vital to consider the population and its influence on groundwater recharge. However, our study was mainly focused on the area of urbanization. As the area of urbanization and population is closely related, and these two factors can produce a doubled influence on groundwater recharge, we only considered the urbanization rate in area. The increased population and the associated potential effect on groundwater should be explored in future studies.

\subsection{The Impacts of Landscape Indices on Water Balance}

Landscape patterns can be easily quantified by different landscape indices such as area, edge, shape, aggregation, and diversity aspects [38]. Meanwhile, the landscape index could concentrate on the landscape information, reflecting the composition of the structural, spatial configuration that links landscape patterns and ecological process. Nowadays, landscape indices metrics are widely used in quantifying the composition and configuration of city expansion and dynamics [56]. Some findings indicated that Patch Density, Aggregation Index, and Splitting Index were sensitive to the different water-quality parameters [57]. However, these studies did not focus on the change of water balance based on the influence of variation of landscape pattern. In our study, we clarified how landscape pattern impacted the water quantity (groundwater recharge and surface runoff). Overall, PD, SPLIT, PRD, and SHDI increased slightly, while AI decreased from 2000 to 2012. The natural landscape, without human disturbance, usually has high AI, low SPLIT and PD, and high vegetation coverage and a large patch. However, along the gradient from outer suburban to urban, with increasing human disturbance, especially impervious surface, the original landscape pattern and underlying surface conditions will be modified. The scattered patches will lead to lower AI and higher SPLIT and PD values, and thus change flow regimes such as runoff directions and rates, and increase the annual runoff [58].

To clarify the influential process of landscape indices and water balance, we sampled the pixels of landscape indices and water balance components layers. These quadrats in Beijing were catalogued into four gradients: outer suburban, suburban, suburban transition zone and urban center. The variations of five landscape indices and water balance at different gradients were analyzed (Figure 9). We observed that PD, SPLIT, PRD, and SHDI generally decreased from outer suburban to urban center with 
fluctuations in suburban transition zone, which had similar tendencies with groundwater recharge. In addition, AI tended to increase with a minimum value in suburban transition zone that had a similar tendency with surface runoff. The special reasons for the differences of landscape indices in outer suburban, suburban, suburban transition zone, and urban area will be studied deeply in future.

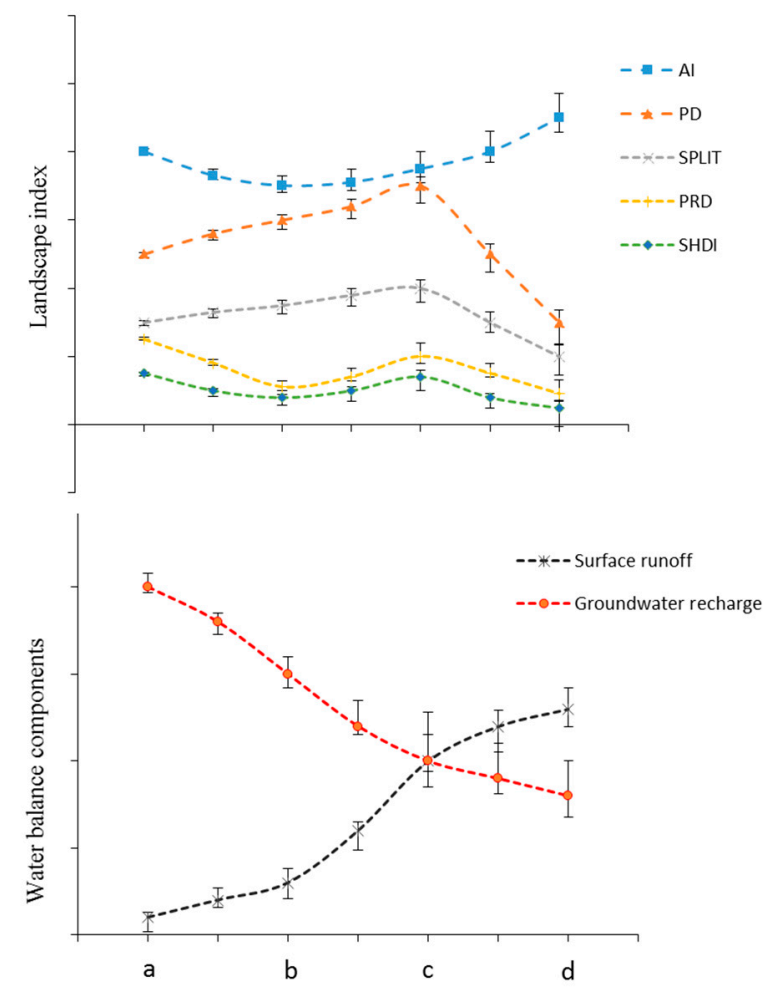

Figure 9. The changing trend of landscape indices and water balance components at four gradients: (a) outer suburban; (b) suburban; (c) suburban transition zone; and (d) urban center.

However, pattern indices alone may not be sufficient to display the whole city landscape changes, so we introduced the impervious percentage and carried out the research at different scales to obtain the quantitative relationships among landscape indices, impervious percentages and water balance components. Previous studies indicated that the urban green spaces, as a measure to reduce surface runoff and alleviate the negative effects on the hydrology in the process of urbanization, have attracted more attention [19]. In addition, for Beijing, the role of urban wetlands has gradually received great attention from urban planners and managers. Wetlands can be identified as natural sponges that would mitigate surface runoff, precipitation, snowmelt, and flood risks [59].

Thus, it will be necessary to increase the green lands, decrease impervious percentages for Beijing and plan the landscape pattern for different districts. Those results are meaningful for the management and spatial planning policymakers in the future.

\section{Conclusions}

In this paper, we mainly studied the effects of urbanization on water balance components and the correlations among water balance components, landscape index, and impervious percentages. The results of the WetSpass model showed that there are significant seasonal differences in surface runoff, groundwater recharge, and evapotranspiration. There was also a clear relationship between land use and water cycle, according to the spatial analysis of different locations. Built-up land and roads resulted in high surface runoff and low groundwater recharge while forests, shrubs, and grassland had the opposite situation. Combining the results of WetSpass in different districts, we found Xicheng, Dongcheng, Haidian, Chaoyang, and other districts where urbanization levels were relatively 
higher had an increasing trend of runoff and a decreased trend of recharge. Moreover, the ranges of higher runoff and lower recharge region have been extended following the urban expansion direction. At quadrat scale, the results of correlation analysis between impervious percentages and hydrological characteristics indicated that impervious percentages and surface runoff presented a decreasing trend when impervious percentages and groundwater recharge displayed an increasing trend. When we studied the effects of landscape pattern on water balance components, we found that AI was positively correlated with surface runoff and negatively with groundwater recharge. PD, PRD, SPLIT, and SHDI were negatively correlated with surface runoff and positively with groundwater recharge.

In conclusion, urbanization changes the land-use type and increases the area of built-up land. As a result, the underlying surface varied, impervious areas increased, and the landscape pattern experienced changes. Finally, the water cycle process was influenced and water balances responded.

Acknowledgments: The research was financially supported by the National Natural Sciences Foundation of China (41530635 and 41571173).

Author Contributions: Yueqiu Zhang and Shiliang Liu conceived and designed the experiments; Yueqiu Zhang performed the experiments and analyzed the data; Fangyan Cheng and Zhenyao Shen contributed reagents/materials/analysis tools; and Yueqiu Zhang wrote the paper.

Conflicts of Interest: The authors declare no conflict of interest. The founding sponsors had no role in the design of the study; in the collection, analyses, or interpretation of data; in the writing of the manuscript, and in the decision to publish the results. 


\section{Appendix A}

Table A1. WetSpass land use parameter.

\begin{tabular}{|c|c|c|c|c|c|c|c|c|c|c|c|c|c|}
\hline NUMBER ER & LUSE_TYPE & RUNOFF_VEG & NUM_VEG_RO & NUM_IMP_RO & VEG_AREA & BARE_AREA & IMP_AREA & OPENW_AREA & ROOT_DEPTH & LAI & MIN_STOM & INTERC_PER & VEG_HEIGHT \\
\hline 1 & Build-up land & grass & 2.00 & 1.00 & 0.20 & 0.00 & 0.80 & 0.00 & 0.30 & 2.00 & 100.00 & 10.00 & 0.12 \\
\hline 2 & $\begin{array}{c}\text { Industural } \\
\text { land }\end{array}$ & grass & 2.00 & 9.00 & 0.40 & 0.00 & 0.60 & 0.00 & 0.30 & 2.00 & 100.00 & 10.00 & 0.12 \\
\hline 3 & Bare land & bare soil & 4.00 & 0.00 & 0.00 & 1.00 & 0.00 & 0.00 & 0.05 & 0.00 & 110.00 & 0.00 & 0.00 \\
\hline 4 & $\begin{array}{l}\text { Agriculture } \\
\text { land }\end{array}$ & crop & 1.00 & 0.00 & 0.00 & 1.00 & 0.00 & 0.00 & 0.35 & 0.00 & 180.00 & 0.00 & 0.60 \\
\hline $\begin{array}{l}5 \\
6\end{array}$ & $\begin{array}{c}\text { Meadow } \\
\text { Wet meadow }\end{array}$ & $\underset{\text { grass }}{\text { grass }}$ & $\begin{array}{l}2.00 \\
2.00\end{array}$ & $\begin{array}{l}0.00 \\
0.00\end{array}$ & $\begin{array}{l}1.00 \\
1.00\end{array}$ & $\begin{array}{l}0.00 \\
0.00\end{array}$ & $\begin{array}{l}0.00 \\
0.00\end{array}$ & $\begin{array}{l}0.00 \\
0.00\end{array}$ & $\begin{array}{l}0.30 \\
0.30\end{array}$ & $\begin{array}{l}2.00 \\
2.00\end{array}$ & $\begin{array}{l}100.00 \\
100.00\end{array}$ & $\begin{array}{l}10.00 \\
10.00\end{array}$ & $\begin{array}{l}0.20 \\
0.30\end{array}$ \\
\hline 7 & $\begin{array}{c}\text { Deciduous } \\
\text { broad- leaved }\end{array}$ & forest & 3.00 & 0.00 & 0.20 & 0.80 & 0.00 & 0.00 & 2.00 & 0.00 & 250.00 & 10.00 & 18.00 \\
\hline 8 & $\begin{array}{l}\text { Evergreen } \\
\text { coniferous } \\
\text { forest }\end{array}$ & forest & 3.00 & 0.00 & 0.90 & 0.10 & 0.00 & 0.00 & 2.00 & 4.50 & 500.00 & 45.00 & 15.00 \\
\hline 9 & Mixed forest & forest & 3.00 & 0.00 & 0.50 & 0.50 & 0.00 & 0.00 & 2.00 & 4.50 & 500.00 & 38.00 & 15.00 \\
\hline 10 & Shrub & grass & 2.00 & 0.00 & 0.20 & 0.80 & 0.00 & 0.00 & 0.60 & 0.00 & 110.00 & 5.00 & 2.00 \\
\hline 11 & Wetland & open water & 5.00 & 0.00 & 0.40 & 0.20 & 0.00 & 0.40 & 0.30 & 2.00 & 110.00 & 10.00 & 0.50 \\
\hline 12 & Lake & open water & 5.00 & 0.00 & 0.00 & 0.00 & 0.00 & 1.00 & 0.05 & 0.00 & 110.00 & 0.00 & 0.00 \\
\hline 13 & River & open water & 5.00 & 0.00 & 0.00 & 0.00 & 0.00 & 1.00 & 0.05 & 0.00 & 110.00 & 0.00 & 0.00 \\
\hline 14 & Road & grass & 2.00 & 5.00 & 0.60 & 0.10 & 0.30 & 0.00 & 0.30 & 2.00 & 100.00 & 10.00 & 0.12 \\
\hline
\end{tabular}

Note: LUSE_TYPE: Land Use Type; RUNOFF_VEG: Runoff Vegetation; NUM_VEG_RO: Runoff class for vegetation type; NUM_IMP_RO: Imprevious Runoff class for impervious area types; VEG_AREA: Vegetated Area; BARE_AREA: Bare Area; IMP_AREA: Impervious Area; OPENW_AREA: Open-water Area; ROOT_DEPTH: Root depth; LAI: Leaf Area Index; MIN_STOM: Minimum Stomatal Opening; INTERC_PER: Interception Percentage; VEG_HEIGHT: Vegetation Height.

Table A2. WetSpass soil parameter.

\begin{tabular}{|c|c|c|c|c|c|c|c|c|c|c|}
\hline NUMBER & SOIL & FIELDCAPAC & WILTINGPNT & PAW & RESIDUALWC & A1 & EVAPODEPTH & TENSIONHHT & P_FRAC_SUM & P_FRAC_WIN \\
\hline 1 & sand & 0.12 & 0.05 & 0.07 & 0.020 & 0.51 & 0.05 & 0.07 & 0.09 & 0.01 \\
\hline 2 & loamy sand & 0.15 & 0.07 & 0.08 & 0.035 & 0.47 & 0.05 & 0.09 & 0.09 & 0.01 \\
\hline 3 & sandy loam & 0.21 & 0.09 & 0.12 & 0.041 & 0.44 & 0.05 & 0.15 & 0.09 & 0.01 \\
\hline 4 & silty loam & 0.29 & 0.10 & 0.19 & 0.015 & 0.40 & 0.05 & 0.21 & 0.26 & 0.07 \\
\hline 5 & loam & 0.25 & 0.12 & 0.13 & 0.027 & 0.37 & 0.05 & 0.11 & 0.15 & 0.02 \\
\hline 6 & sandy clayl & 0.26 & 0.16 & 0.10 & 0.068 & 0.32 & 0.05 & 0.28 & 0.54 & 0.30 \\
\hline 7 & clayloa m & 0.33 & 0.19 & 0.14 & 0.075 & 0.27 & 0.05 & 0.26 & 0.62 & 0.41 \\
\hline 8 & clay & 0.46 & 0.33 & 0.13 & 0.090 & 0.21 & 0.05 & 0.37 & 0.95 & 0.85 \\
\hline
\end{tabular}

Note: NUMBER: Soil type number; SOIL: Soil type (texture); FIELDCAPAC: Field capacity; WILTINGPNT: Wilting Point; PAW: Plant available water content; RESIDUALWC: Residual

water content; A1: Calibration parameter dependent on the sand content of the soil; EVAPODEPTH: Bare soil evaporation depth; TENSIONHHT: Tension saturated height; P FRAC SUM:

Fraction of summer precipitaion contributing to Hortonian runoff; P_FRAC_WIN: Fraction of winter precipitaion contributing to Hortonian runoff. 
Table A3. Runoff coefficient parameters for vegetated, bare soil and open water raster cells.

\begin{tabular}{|c|c|c|c|c|c|c|c|c|c|c|c|c|c|c|c|}
\hline LANDUSERO & LANDUSENUM & SLOPE_[\%] & SLOPENUM & SOILTYPE & SOILNUM & RUNOFFCOEF & UNIQUE_NUM & SOIL_BARE & SLOPE_BARE & BAREROCOEF & UNIQUEBARE & NUM_IMP_RO & SLOPE_IMP & IMPROCOEF & UNIQUEIMP \\
\hline crop & 1 & $<0.5$ & 1 & sand & 1 & 0.3500 & 111 & 1 & 1 & 0.4500 & 11 & 1 & 1 & 0.50 & 11 \\
\hline crop & 1 & $0.5-5$ & 2 & sand & 1 & 0.4000 & 112 & 1 & 2 & 0.4800 & 12 & 1 & 2 & 0.60 & 12 \\
\hline crop & 1 & $5-10$ & 3 & sand & 1 & 0.4500 & 113 & 1 & 3 & 0.5300 & 13 & 1 & 3 & 0.70 & 13 \\
\hline crop & 1 & $>10$ & 4 & sand & 1 & 0.5000 & 114 & 1 & 4 & 0.5800 & 14 & 1 & 4 & 0.80 & 14 \\
\hline 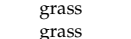 & 2 & $\begin{array}{l}<0.5 \\
0.5\end{array}$ & 1 & $\begin{array}{l}\text { sand } \\
\text { sand }\end{array}$ & 1 & 0.1500 & 121 & 2 & 1 & 0.4800 & 21 & 2 & 1 & 0.40 & 21 \\
\hline $\begin{array}{l}\text { grass } \\
\text { grass }\end{array}$ & $\begin{array}{l}2 \\
2\end{array}$ & $\begin{array}{l}0.5-5 \\
5-10\end{array}$ & ${ }_{3}^{2}$ & $\begin{array}{l}\text { Sand } \\
\text { sand }\end{array}$ & $\begin{array}{l}1 \\
1\end{array}$ & $\begin{array}{l}0.2000 \\
0.2500\end{array}$ & $\begin{array}{l}122 \\
123\end{array}$ & $\begin{array}{l}2 \\
2\end{array}$ & $\begin{array}{l}2 \\
3\end{array}$ & $\begin{array}{l}0.5300 \\
0.5800\end{array}$ & $\begin{array}{l}22 \\
23\end{array}$ & 2 & $\begin{array}{l}2 \\
3\end{array}$ & $\begin{array}{l}0.50 \\
0.60\end{array}$ & $\begin{array}{l}22 \\
23\end{array}$ \\
\hline $\begin{array}{l}\text { grass } \\
\text { grass }\end{array}$ & 2 & $\begin{array}{l}5-10 \\
>10\end{array}$ & 4 & $\begin{array}{l}\text { Sand } \\
\text { sand }\end{array}$ & 1 & $\begin{array}{l}0.2500 \\
0.3000\end{array}$ & 124 & 2 & 4 & $\begin{array}{l}0.5300 \\
0.6300\end{array}$ & 24 & 2 & 4 & 0.70 & 24 \\
\hline forest & 3 & $<0.5$ & 1 & sand & 1 & 0.0500 & 131 & 3 & $\begin{array}{l}4 \\
1\end{array}$ & 0.5000 & 31 & 3 & $\begin{array}{l}4 \\
1\end{array}$ & 0.30 & 31 \\
\hline forest & 3 & $0.5-5$ & 2 & sand & 1 & 0.1000 & 132 & 3 & 2 & 0.5500 & 32 & 3 & 2 & 0.40 & 32 \\
\hline forest & & 5-10 & & sand & & 0.1500 & 133 & 3 & 3 & 0.6000 & 33 & 3 & 3 & 0.50 & 33 \\
\hline forest & 3 & $>10$ & 4 & sand & 1 & 0.2000 & 134 & 3 & 4 & 0.6500 & 34 & 3 & 4 & 0.60 & 34 \\
\hline bare soil & 4 & $<0.5$ & 1 & sand & 1 & 0.4500 & 141 & 4 & 1 & 0.5300 & 41 & 4 & 1 & 0.30 & 41 \\
\hline bare soil & 4 & $0.5-5$ & 2 & sand & 1 & 0.4800 & 142 & 4 & 2 & 0.5800 & 42 & 4 & 2 & 0.40 & 42 \\
\hline bare soil & 4 & $>10$ & 4 & sand & 1 & 0.5800 & 144 & 4 & 4 & 0.6800 & 44 & 4 & 4 & 0.60 & 44 \\
\hline openwater & 5 & $<0.5$ & 1 & sand & 1 & $\begin{array}{l}1.0000 \\
1.000\end{array}$ & 151 & 5 & 1 & 0.5000 & 51 & 5 & 1 & 0.30 & 51 \\
\hline $\begin{array}{l}\text { openwater } \\
\text { openwwater }\end{array}$ & $\begin{array}{l}5 \\
5\end{array}$ & $\begin{array}{l}0.5-5 \\
5-10\end{array}$ & ${ }_{3}^{2}$ & $\begin{array}{l}\text { sand } \\
\text { sand }\end{array}$ & 1 & 1.0000 & 152 & 5 & 2 & 0.5500 & 52 & 5 & 2 & 0.40 & 52 \\
\hline & $\begin{array}{l}5 \\
5\end{array}$ & $\begin{array}{l}5-10 \\
>10\end{array}$ & $\begin{array}{l}3 \\
4\end{array}$ & $\begin{array}{l}\text { sand } \\
\text { sand }\end{array}$ & $\begin{array}{l}1 \\
1\end{array}$ & $\begin{array}{l}1.0000 \\
1.0000\end{array}$ & $\begin{array}{l}153 \\
154\end{array}$ & $\begin{array}{l}5 \\
5\end{array}$ & $\begin{array}{l}3 \\
4\end{array}$ & $\begin{array}{l}0.6000 \\
0.6500\end{array}$ & $\begin{array}{l}53 \\
54\end{array}$ & $\begin{array}{l}5 \\
5\end{array}$ & $\begin{array}{l}3 \\
4\end{array}$ & $\begin{array}{l}0.50 \\
0.60\end{array}$ & $\begin{array}{l}53 \\
54\end{array}$ \\
\hline $\begin{array}{l}\text { openwater } \\
\text { crop }\end{array}$ & $\begin{array}{l}5 \\
1\end{array}$ & $\begin{array}{l}>10 \\
<0.5\end{array}$ & $\begin{array}{l}4 \\
1\end{array}$ & $\begin{array}{l}\text { sand } \\
\text { Loamy-sand }\end{array}$ & $\begin{array}{l}1 \\
2\end{array}$ & $\begin{array}{l}\begin{array}{l}1.00000 \\
0.3800\end{array}\end{array}$ & $\begin{array}{l}154 \\
211\end{array}$ & $\begin{array}{l}5 \\
6\end{array}$ & $\begin{array}{l}4 \\
1\end{array}$ & $\begin{array}{l}0.6000 \\
0.4800\end{array}$ & $\begin{array}{l}54 \\
61\end{array}$ & $\begin{array}{l}5 \\
6\end{array}$ & $\begin{array}{l}4 \\
1\end{array}$ & 0.30 & $\begin{array}{l}54 \\
61\end{array}$ \\
\hline crop & 1 & $0.5-5$ & 2 & loamy-sand & 2 & 0.4300 & 212 & 6 & 2 & 0.5300 & 62 & 6 & 2 & 0.40 & 62 \\
\hline crop & 1 & $5-10$ & 3 & loamy-sand & 2 & 0.4800 & 213 & 6 & 3 & 0.5800 & 63 & 6 & 3 & 0.50 & 63 \\
\hline crop & 1 & $>10$ & 4 & loamy-sand & 2 & 0.5300 & 214 & 6 & 4 & 0.6300 & 64 & 6 & 4 & 0.60 & 64 \\
\hline grass & 2 & $<0.5$ & 1 & loamy-sand & 2 & 0.1800 & 221 & 7 & 1 & 0.5300 & 71 & 7 & 1 & 0.30 & 71 \\
\hline grass & 2 & $0.5-5$ & 2 & loamy-sand & 2 & 0.2300 & 222 & 7 & 2 & 0.5800 & 72 & 7 & 2 & 0.40 & 72 \\
\hline grass & 2 & $5-10$ & 3 & loamy-sand & 2 & 0.2800 & 223 & 7 & 3 & 0.6300 & 73 & 7 & 3 & 0.50 & 73 \\
\hline grass & 2 & $>10$ & 4 & loamy-sand & 2 & 0.3300 & 224 & 7 & 4 & 0.6800 & 74 & 7 & 4 & 0.60 & 74 \\
\hline forest & 3 & $<0.5$ & 1 & loamy-sand & 2 & 0.0800 & 231 & 8 & 1 & 0.5500 & 81 & 8 & 1 & 0.50 & 81 \\
\hline forest & 3 & $0.5-5$ & 2 & loamy-sand & & 0.1300 & 232 & 8 & 2 & 0.5800 & 82 & 8 & 2 & 0.60 & 82 \\
\hline bare soil & 4 & $0.5-5$ & 2 & loamy-sand & 2 & 0.5300 & 242 & 9 & 2 & 0.6300 & 92 & 9 & 2 & 0.40 & 92 \\
\hline bare soil & 4 & $5-10$ & 3 & loamy-sand & 2 & 0.5800 & 243 & 9 & 3 & 0.6800 & 93 & 9 & 3 & 0.50 & 93 \\
\hline bare soil & 4 & $>10$ & 4 & loamy-sand & 2 & 0.6300 & 244 & 9 & 4 & 0.7300 & 94 & 9 & 4 & 0.60 & 94 \\
\hline openwater & 5 & $<0.5$ & 1 & loamy-sand & 2 & 1.0000 & 251 & 10 & 1 & 0.6000 & 101 & & & 0.00 & \\
\hline $\begin{array}{l}\text { openwater } \\
\text { openwater }\end{array}$ & $\begin{array}{l}5 \\
5\end{array}$ & $\begin{array}{l}0.5-5 \\
5-10\end{array}$ & $\begin{array}{l}2 \\
3\end{array}$ & $\begin{array}{l}\text { loamy-sand } \\
\text { loamy-sand }\end{array}$ & $\begin{array}{l}2 \\
2\end{array}$ & $\begin{array}{l}1.0000 \\
10000\end{array}$ & $\begin{array}{l}252 \\
253\end{array}$ & $\begin{array}{l}10 \\
10\end{array}$ & ${ }_{3}^{2}$ & 0.6500 & 102 & & & 0.00 & \\
\hline $\begin{array}{l}\text { openwater } \\
\text { openwater }\end{array}$ & $\begin{array}{l}5 \\
5\end{array}$ & $\begin{array}{l}5-10 \\
>10\end{array}$ & $\begin{array}{l}3 \\
4\end{array}$ & $\begin{array}{l}\text { loamy-sand } \\
\text { loamy-sand }\end{array}$ & $\begin{array}{l}2 \\
2\end{array}$ & $\begin{array}{l}1.0000 \\
1.0000\end{array}$ & $\begin{array}{l}253 \\
254\end{array}$ & $\begin{array}{l}10 \\
10\end{array}$ & $\begin{array}{l}3 \\
4\end{array}$ & $\begin{array}{l}0.7000 \\
0.7500\end{array}$ & $\begin{array}{l}103 \\
104\end{array}$ & & & $\begin{array}{l}0.000 \\
0.00\end{array}$ & \\
\hline $\begin{array}{l}\text { openwater } \\
\text { crop }\end{array}$ & 1 & $<0.5$ & $\begin{array}{l}4 \\
1\end{array}$ & $\begin{array}{l}\text { loamy-sand } \\
\text { sandy-loam }\end{array}$ & 3 & $\begin{array}{l}1.4000 \\
0.400\end{array}$ & $\begin{array}{l}354 \\
311\end{array}$ & 11 & $\begin{array}{l}4 \\
1\end{array}$ & 0.6300 & 111 & & & 0.00 & \\
\hline crop & 1 & $0.5-5$ & 2 & sandy-loam & 3 & $\begin{array}{l}0.4500 \\
0.4500\end{array}$ & 312 & 11 & 2 & 0.6800 & 112 & & & 0.00 & \\
\hline crop & 1 & 5-10 & 3 & sandy-loam & 3 & 0.5000 & 313 & 11 & 3 & 0.7300 & 113 & & & 0.00 & \\
\hline crop & 1 & $>10$ & 4 & sandy-loam & 3 & & 314 & 11 & 4 & 0.7800 & 114 & & & 0.00 & \\
\hline grass & 2 & $<0.5$ & 1 & sandy-loam & 3 & 0.2000 & 321 & 12 & 1 & 0.6500 & 121 & & & 0.00 & \\
\hline grass & 2 & $0.5-5$ & 2 & sandy-loam & 3 & 0.2500 & 322 & 12 & 2 & 0.7000 & 122 & & & 0.00 & \\
\hline grass & 2 & $5-10$ & 3 & sandy-loam & 3 & 0.3000 & 323 & 12 & 3 & 0.7500 & 123 & & & 0.00 & \\
\hline grass & 2 & $>10$ & 4 & sandy-loam & 3 & 0.3500 & 324 & 12 & 4 & 0.8000 & 124 & & & 0.00 & \\
\hline forest & 3 & $<0.5$ & 1 & sandy-loam & 3 & & 331 & & & 0.0000 & & & & 0.00 & \\
\hline forest & 3 & $0.5-5$ & 2 & sandy-loam & 3 & 0.1500 & 332 & & & 0.0000 & & & & 0.00 & \\
\hline $\begin{array}{l}\text { 仵est } \\
\text { forest }\end{array}$ & 3 & $\begin{array}{c}5-10 \\
>10\end{array}$ & 3 & sandy-loam & 3 & 0.2000 & 333 & & & 0.0000 & & & & 0.00 & \\
\hline $\begin{array}{c}\text { forest } \\
\text { bare soil }\end{array}$ & $\begin{array}{l}3 \\
4\end{array}$ & $\begin{array}{l}>10 \\
<0.5\end{array}$ & $\begin{array}{l}4 \\
1\end{array}$ & $\begin{array}{l}\text { sandy-loam } \\
\text { sandy-loam }\end{array}$ & $\begin{array}{l}3 \\
3\end{array}$ & $\begin{array}{l}0.2500 \\
0.5000\end{array}$ & $\begin{array}{l}334 \\
341\end{array}$ & & & $\begin{array}{l}0.0000 \\
0.0000\end{array}$ & & & & $\begin{array}{l}0.00 \\
0.00\end{array}$ & \\
\hline bare soil & $\begin{array}{l}4 \\
4\end{array}$ & $\begin{array}{l}<0.5 \\
0.5-5\end{array}$ & $\begin{array}{l}1 \\
2\end{array}$ & $\begin{array}{l}\text { Sandy-1oam } \\
\text { Sandy-loam }\end{array}$ & $\begin{array}{l}3 \\
3\end{array}$ & $\begin{array}{l}0.5000 \\
0.5500\end{array}$ & $\begin{array}{l}341 \\
342\end{array}$ & & & $\begin{array}{l}0.00000 \\
0.0000\end{array}$ & & & & 0.00 & \\
\hline bare soil & 4 & 5-10 & 3 & sandy-loam & 3 & 0.6000 & 343 & 0.0000 & 0.00 & & & & & & \\
\hline bare soil & 4 & $>10$ & 4 & sandy-loam & 3 & 0.6500 & 344 & 0.0000 & 0.00 & & & & & & \\
\hline openwater & 5 & $<0.5$ & 1 & sandy-loam & 3 & 1.0000 & 351 & 0.0000 & 0.00 & & & & & & \\
\hline openwater & 5 & $0.5-5$ & 2 & sandy-loam & 3 & 1.0000 & 352 & 0.0000 & 0.00 & & & & & & \\
\hline $\begin{array}{l}\text { openwater } \\
\text { openwater }\end{array}$ & 5 & $5-10$ & 3 & $\begin{array}{l}\text { sandy-loam } \\
\text { sandy-loman }\end{array}$ & 3 & $\begin{array}{l}1.0000 \\
1.000\end{array}$ & 353 & 0.0000 & 0.00 & & & & & & \\
\hline openwater & 5 & $>10$ & 4 & sandy-loam & 3 & 1.0000 & 354 & 0.0000 & 0.00 & & & & & & \\
\hline
\end{tabular}


Table A3. Cont.

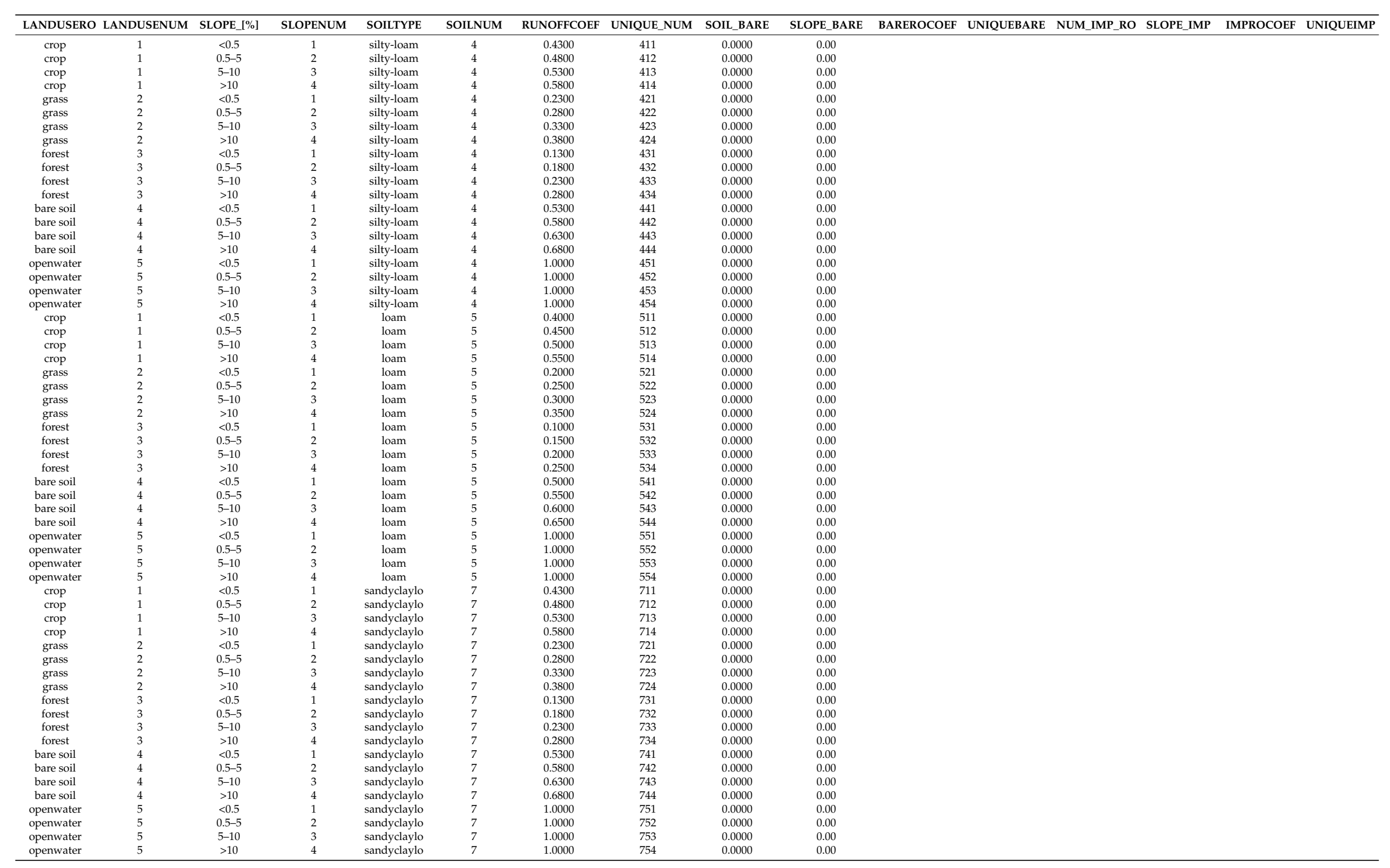


Table A3. Cont.

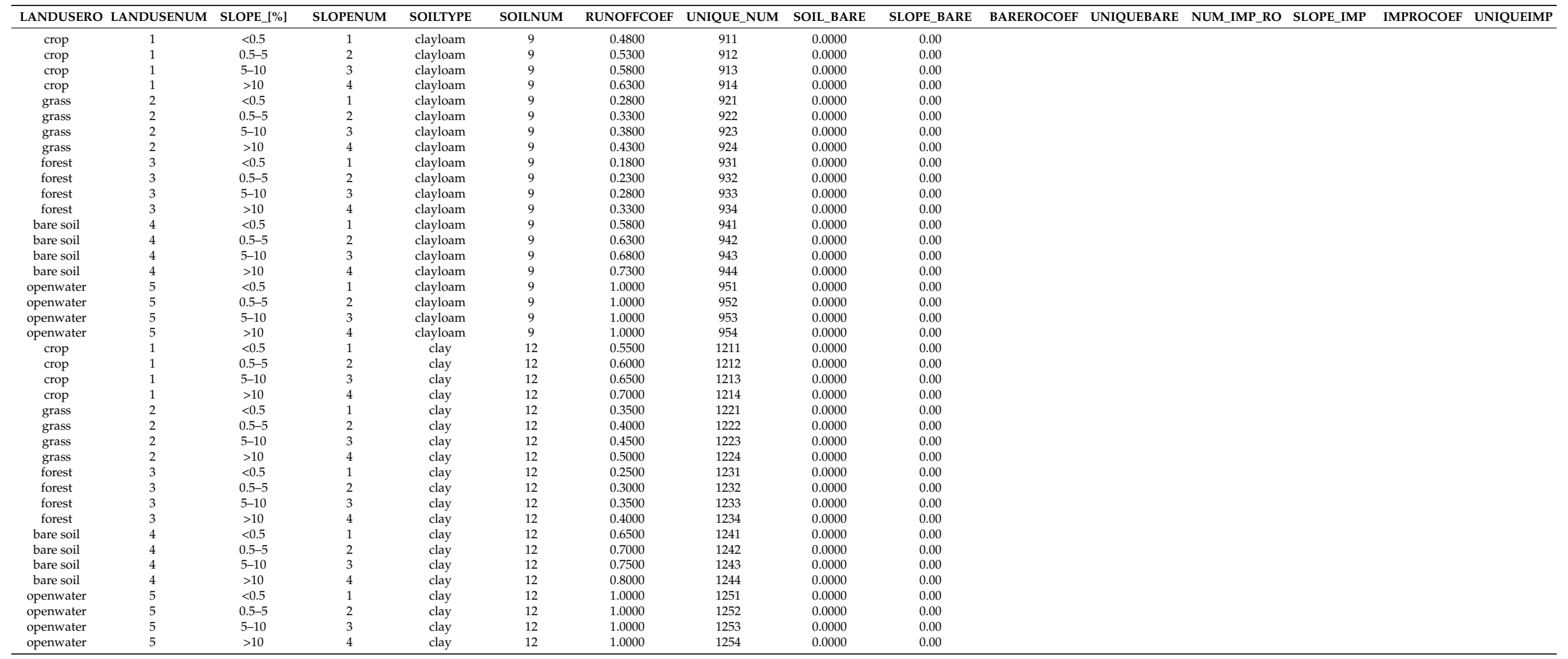

Note: LANDUSERO: Runoff class for landuse; LANDUSENUM: Number of runoff class for landuse; SLOPE_[\%]: Slope; SLOPENUM: Slope class; SOILTYPE: Soil type; SOILNUM: Soil class; RUNOFFCOEF: Runoff coefficient; UNIQUE_NUM: Unique Number $(100 \times$ SOILNUM + $10 \times$ LANDUSENUM + $1 \times$ SLOPENUM); SOIL_BARE: Soil type (bare); SLOPE_BARE: Slope class of bare soil; BARECOEF: Bare soil runoff coefficient; UNIQUEBARE: Unique Number $(10 \times$ SOIL_BARE + $1 \times$ SLOPE_BARE); IMPLUSERO: Impervious landuse runoff; NUM_IMP_RO: Impervious landuse runoff class; SLOPE_IMP: Slope class of impervious landuse type; IMROCOEF: Runoff coefficient for impervious landuse type; UNIQUEIMP: Unique Number $(10 \times$ NUM_IMP_RO + $1 \times$ SLOPE_IMP). 
Table A4. The location of monitoring points.

\begin{tabular}{|c|c|c|c|c|}
\hline Monitoringpoints & Location & Latitude Andlongitude & Groundwaterdepth (m) & $\Delta h(\mathrm{~m})$ \\
\hline 0 & Qingyang village in Pinggu district & $40^{\circ} 6^{\prime} 5.09^{\prime \prime} \mathrm{N}, 117^{\circ} 4^{\prime} 6.10^{\prime \prime} \mathrm{E}$ & 25.32 & 1.71 \\
\hline 1 & Chenjiaying village in Chengguan town of Yanging country & $40^{\circ} 27^{\prime} 25.34^{\prime \prime} \mathrm{N}, 116^{\circ} 2^{\prime} 8.10^{\prime \prime} \mathrm{E}$ & 13.97 & 11.8 \\
\hline 2 & Xiyangfang village in Lejiabao of Yanqingcountry & $40^{\circ} 31^{\prime} 6.05^{\prime \prime} \mathrm{N}, 115^{\circ} 55^{\prime} 7.34^{\prime \prime} \mathrm{E}$ & 13.70 & 1.08 \\
\hline 3 & Xiaonanyuan in Yongning town of Yanqingcountry & $40^{\circ} 31^{\prime} 41.67^{\prime \prime} \mathrm{N}, 116^{\circ} 9^{\prime} 48.53^{\prime \prime} \mathrm{E}$ & 9.84 & 1.7 \\
\hline 4 & Shahe village in Chengguan town of Miyuncountry & $40^{\circ} 23^{\prime} 34.24^{\prime \prime} \mathrm{N}, 116^{\circ} 51^{\prime} 8.85^{\prime \prime} \mathrm{E}$ & 26.91 & 3.18 \\
\hline 5 & Menlou village in Pinggu district & $40^{\circ} 4^{\prime} 42.10^{\prime \prime} \mathrm{N}, 117^{\circ} 3^{\prime} 28.42^{\prime \prime} \mathrm{E}$ & 1.77 & 3.95 \\
\hline 6 & Tianjiaying in Shunyi district & $40^{\circ} 6^{\prime} 31.43^{\prime \prime} \mathrm{N}, 116^{\circ} 48^{\prime} 12.30^{\prime \prime} \mathrm{E}$ & 14.72 & 1.66 \\
\hline 7 & Changziying in Daxing district & $39^{\circ} 41^{\prime} 14.73^{\prime \prime} \mathrm{N}, 116^{\circ} 35^{\prime} 11.77^{\prime \prime} \mathrm{E}$ & 4.55 & 4.32 \\
\hline 8 & Xiaotangshan village in Xiaotangshan town ofChangping district & $40^{\circ} 10^{\prime} 14.03^{\prime \prime} \mathrm{N}, 116^{\circ} 22^{\prime} 41.83^{\prime \prime} \mathrm{E}$ & 2.21 & 5.25 \\
\hline 9 & Yangzhenerie in Shunyi district & $40^{\circ} 9^{\prime} 0.43^{\prime \prime} \mathrm{N}, 116^{\circ} 49^{\prime} 39.30^{\prime \prime} \mathrm{E}$ & 2.48 & 1.63 \\
\hline 10 & Henan village in Shunyi district & $40^{\circ} 6^{\prime} 14.31^{\prime \prime} \mathrm{N}, 116^{\circ} 42^{\prime} 12.80^{\prime \prime} \mathrm{E}$ & 6.47 & 8.74 \\
\hline 11 & Nanhuofa in Tongzhou district & $39^{\circ} 47^{\prime} 56.62^{\prime \prime} \mathrm{N}, 116^{\circ} 39^{\prime} 46.09^{\prime \prime} \mathrm{E}$ & 2.43 & 2.51 \\
\hline 12 & Dongran village in Haidian district & $39^{\circ} 57^{\prime} 15.85^{\prime \prime} \mathrm{N}, 116^{\circ} 16^{\prime} 14.79^{\prime \prime} \mathrm{E}$ & 30.31 & 3.95 \\
\hline 13 & Tsinghua University in Haidian district & $39^{\circ} 59^{\prime} 58.80^{\prime \prime} \mathrm{N}, 116^{\circ} 19^{\prime} 35.20^{\prime \prime} \mathrm{E}$ & 31.07 & 4.82 \\
\hline 14 & Peking University in Haidian district & $39^{\circ} 59^{\prime} 12.82^{\prime \prime} \mathrm{N}, 116^{\circ} 18^{\prime} 21.04^{\prime \prime} \mathrm{E}$ & 25.54 & 5.03 \\
\hline 15 & Dahongmen in Fengtai district & $39^{\circ} 49^{\prime} 40.13^{\prime \prime} \mathrm{N}, 116^{\circ} 25^{\prime} 5.79^{\prime \prime} \mathrm{E}$ & 23.91 & 0.53 \\
\hline 16 & Baliqiao village in Chaoyang district & $39^{\circ} 54^{\prime} 35.61^{\prime \prime} \mathrm{N}, 116^{\circ} 36^{\prime} 55.99^{\prime \prime} \mathrm{E}$ & 58.77 & 2.79 \\
\hline 17 & Working people's Cultural Palace in Dongchengdistrict & $39^{\circ} 54^{\prime} 38.35^{\prime \prime} \mathrm{N}, 116^{\circ} 24^{\prime} 0.57^{\prime \prime} \mathrm{E}$ & 27.47 & 1.49 \\
\hline 18 & Xingli village in Fangshan district & $39^{\circ} 35^{\prime} 49.64^{\prime \prime} \mathrm{N}, 116^{\circ} 4^{\prime} 59.75 \mathrm{E}$ & 5.05 & 9.16 \\
\hline 19 & Liangxiang Development Zone in Fangshandistrict & $39^{\circ} 42^{\prime} 28.84^{\prime \prime} \mathrm{N}, 116^{\circ} 12^{\prime} 16.75^{\prime \prime} \mathrm{E}$ & 16.68 & 5.57 \\
\hline 20 & Lizhuang village in Fangshan district & $39^{\circ} 35^{\prime} 56.17^{\prime \prime} \mathrm{N}, 116^{\circ} 0^{\prime} 27.92^{\prime \prime} \mathrm{E}$ & 8.45 & 9.18 \\
\hline 21 & Capital Normal University in Haidian district & $39^{\circ} 55^{\prime} 49.09^{\prime \prime} \mathrm{N}, 116^{\circ} 18^{\prime} 27.63^{\prime \prime} \mathrm{E}$ & 32.49 & 2.21 \\
\hline 22 & Tiantan Park & $39^{\circ} 53^{\prime} 1.39^{\prime \prime} \mathrm{N}, 116^{\circ} 24^{\prime} 45.93^{\prime \prime} \mathrm{E}$ & 28.44 & 1.1 \\
\hline 23 & Dingfu village of Chaoyang district & $39^{\circ} 55^{\prime} 7.42^{\prime \prime} \mathrm{N}, 116^{\circ} 33^{\prime} 59.34^{\prime \prime} \mathrm{E}$ & 2.93 & 1.5 \\
\hline 24 & Luhe middle school in Tongzhou district & $39^{\circ} 53^{\prime} 56.82^{\prime \prime} \mathrm{N}, 116^{\circ} 39^{\prime} 23.63^{\prime \prime} \mathrm{E}$ & 15.87 & 5.13 \\
\hline 25 & Water source plant in Fengtai district & $39^{\circ} 51^{\prime} 49.68^{\prime \prime} \mathrm{N}, 116^{\circ} 19^{\prime} 6.05^{\prime \prime} \mathrm{E}$ & 24.22 & 2.5 \\
\hline 26 & Yuquan mountain in Haidian district & $39^{\circ} 59^{\prime} 38.15^{\prime \prime} \mathrm{N}, 116^{\circ} 14^{\prime} 52.83^{\prime \prime} \mathrm{E}$ & 33.03 & 7.62 \\
\hline
\end{tabular}

Note: Groundwater depth and water level variation $(\Delta h)$ is the annual average values. 


\section{References}

1. Han, D.; Currell, M.J.; Cao, G.; Hall, B. Alterations to groundwater recharge due to anthropogenic landscape change. J. Hydrol. 2017, 554, 545-557. [CrossRef]

2. Yang, Y.; Lerner, D.N.; Barrett, M.H.; Tellam, J.H. Quantification of groundwater recharge in the city of Nottingham, UK. Environ. Geol. 1999, 38, 183-198. [CrossRef]

3. Liu, Y.; Gebremeskel, S.; Smedt, F.D.; Hoffmann, L. Predicting storm runoff from different land-use classes using a geographical information systembased distributed model. J. Hydrol. 2006, 20, 533-548.

4. Dow, C.L.; DeWalle, D.R. Trends in evaporation and bowen ratio on urbanizing watersheds in eastern United States. Water Resour. Res. 2000, 36, 1835-1843. [CrossRef]

5. Larsen, T.A.; Hoffmann, S.; Lüthi, C.; Truffer, B.; Maurer, M. Emerging solutions to the water challenges of an urbanizing world. Science 2016, 352, 928-933. [CrossRef] [PubMed]

6. Zhou, L.; Dickinson, R.E.; Tian, Y.; Fang, J.; Li, Q.; Kaufmann, R.K.; Tucker, C.J.; Myneni, R.B. Evidence for a significant urbanization effect on climate in China. Proc. Natl. Acad. Sci. USA 2004, 101, 9540-9544. [CrossRef] [PubMed]

7. $\mathrm{Fu}, \mathrm{P}$. A time series analysis of urbanization induced land use and land cover change and its impact on land surface temperature with landsat imagery. Remote Sens. Environ. 2016, 175, 205-214. [CrossRef]

8. Su, S.; Ma, X.; Xiao, R. Agricultural landscape pattern changes in response to urbanization at ecoregional scale. Ecol. Indic. 2014, 40, 10-18. [CrossRef]

9. Tian, Y.; Jim, C.Y.; Wang, H. Assessing the landscape and ecological quality of urban green spaces in a compact city. Landsc. Urban Plan. 2014, 121, 97-108. [CrossRef]

10. Kadish, J.; Netusil, N. Valuing vegetation in an urban watershed. Landsc. Urban Plan. 2012, 104, 59-65. [CrossRef]

11. Davies, A.S.; Hernebring, C.; Svensson, G. The impacts of climate change and urbanisation on drainage in helsingborg, sweden: Suburban stormwater. J. Hydrol. 2008, 350, 114-125. [CrossRef]

12. Poelmans, L.; Rompaey, A.; Batelaan, O. Coupling urban expansion models and hydrological models: How important are spatial patterns? Land Use Policy 2010, 27, 965-975. [CrossRef]

13. Huang, T.; Li, X.; Rijnaarts, H.; Grotenhuis, T. Effects of storm runoff on the thermal regime and water quality of a deep, stratified reservoir in a temperate monsoon zone, in northwest China. Sci. Total Environ. 2014, 485, 820-827. [CrossRef] [PubMed]

14. Corbett, D.R.; Chanton, J.; Burnett, W.; Dillon, K.; Rutkowski, C.; Fourqurean, J.W. Patterns of groundwater discharge into Florida Bay. Limnol. Oceanogr. 1999, 44, 1045-1055. [CrossRef]

15. Rose, S.; Peters, N.E. Effects of urbanization on streamflow in the Atlanta area (Georgia, USA): A comparative hydrological approach. Hydrol. Process. 2001, 15, 1441-1457. [CrossRef]

16. Grischek, T.; Nestler, W.; Piechniczek, D.; Fischer, T. Urban groundwater in Dresden, Germany. Hydrogeol. J. 1996, 4, 48-63. [CrossRef]

17. Kalin, L.; Hantush, M.M. Hydrologic modeling of an eastern Pennsylvania watershed with NEXRAD and rain gauge data. J. Hydrol. Eng. 2006, 11, 555-569. [CrossRef]

18. Barron, O.V.; Donn, M.J.; Barr, A.D. Urbanisation and shallow groundwater: predicting changes in catchment hydrological responses. Water Resour. Manag. 2013, 27, 95-115. [CrossRef]

19. Zhang, D.; Madsen, H.; Ridler, M.E.; Refsgaard, J.C. Impact of uncertainty description on assimilating hydraulic head in the MIKE SHE distributed hydrological model. Adv. Water Resour. 2015, 86, 400-413. [CrossRef]

20. Gumindoga, W.; Rientjes, T.; Haile, A.; Dube, T. Predicting streamflow for land cover changes in the upper Gilgel Abay River basin, Ethiopia: A TOPMODEL based approach. Phys. Chem. Earth 2014, 76, 3-15. [CrossRef]

21. Singh, G.; Saraswat, D. Development and evaluation of targeted marginal land mapping approach in SWAT model for simulating water quality impacts of selected second generation biofeedstock. Environ. Model. Softw. 2016, 81, 26-39. [CrossRef]

22. Gebreyohannes, T.; Smedt, F.; Walraevens, K.; Gebresilassie, S. Application of a spatially distributed water balance model for assessing surface water and groundwater resources in the Geba basin, Tigray, Ethiopia. J. Hydrol. 2013, 499, 110-123. [CrossRef] 
23. Batelaan, O.; Wang, Z.; de Smedt, F. An adaptive GIS toolbox for hydrological modelling. In Application of Geographic Information Systems in Hydrology and Water Resources Management; Kovar, K., Nachtnebel, H.P., Eds.; International Association of Hydrological Sciences: Wallingford, UK, 1996; pp. 3-9.

24. Moiwo, J.P.; Tao, F. Groundwater recharge and discharge analysis for Land use conditions suitable for the hydrology and ecology of semiarid regions. Hydrol. Res. 2014, 45, 563. [CrossRef]

25. Wang, Y.; Lei, X.; Liao, W.; Jiang, Y.; Huang, X.; Liu, J.; Song, X.; Wang, H. Monthly spatial distributed water resources assessment: A case study. Comput. Geosci. 2012, 45, 319-330. [CrossRef]

26. Zomlot, Z.; Verbeiren, B.; Huysmans, M.; Batelaan, O. Spatial distribution of groundwater recharge and base flow: Assessment of controlling factors. J. Hydrol. 2015, 4, 349-368. [CrossRef]

27. Zomlot, Z.; Verbeiren, B.; Huysmans, M.; Batelaan, O. Trajectory analysis of land use and land cover maps to improve spatial-temporal patterns, and impact assessment on groundwater recharge. J. Hydrol. 2017, 554, 558-569. [CrossRef]

28. Lin, L.; Yin, Y.; Xie, Y. Study on rainfall infiltration recharge under conditions of difference land use and cover in Songnen basin. Water Resour. Hydropower Northeast 2011, 1, 35-37. (In Chinese)

29. Dams, J.; Dujardin, J.; Reggers, R.; Bashir, I. Mapping impervious surface change from remote sensing for hydrological modeling. J. Hydrol. 2013, 485, 84-95. [CrossRef]

30. Jiang, Y.; Tian, F.; Luo, Y.; Wang, R. Research on the relationship between groundwater level and layered subsidence in typical regions of Beijing. South-to-North Water Transf. Water Sci. Technol. 2015, 13, 95-99. (In Chinese)

31. Bureau, B.S. Beijing Statistical Yearbook 2010; China Statistics Press: Beijing, China, 2010. (In Chinese)

32. Qiao, Z.; Tian, G.; Xiao, L. Diurnal and seasonal impacts of urbanization on the urban thermal environment: A case study of Beijing using MODIS data. ISPRS J. Photogramm. Remote Sens. 2013, 85, 93-107. [CrossRef]

33. Sun, Z.; Feng, S.; Yang, Z.; Wu, H. Primary analysis of the precipitation characteristics for Beijing during the period from 1950 to 2005. J. Irrig. Drain. 2007, 26, 12-16.

34. Pan, Y.; Zhu, L.; Du, L.; Xu, H. Estimation of rainfall infiltration in Beijing plain using WetSpass. J. Water Resour. Res. 2012, 1, 245-250. (In Chinese) [CrossRef]

35. Tong, Y.; Wang, Y. Dynamic simulation and policy analysis of Beijing population. China Popul. Ressour. Environ. 2016, 26, 170-176. (In Chinses)

36. Wang, J.; Yang, F.; He, B.; Zhao, L. Study on reducing shadow impact in the extraction impervious surface coverage of urban based on quickbird image. Remote Sens. Inf. 2008, 3, 69-73. (In Chinese)

37. Shen, Z.; Hou, X.; Li, W.; Aini, G.; Chen, L.; Gong, Y. Impact of landscape pattern at multiple spatial scales on water quality: A case study in a typical urbanised watershed in China. Ecol. Indic. 2015, 48, 417-427. [CrossRef]

38. Mcgarigal, K. Fragstats: Spatial Pattern Analysis Software for Categorical Maps; University of Massachusetts: Amherst, MA, USA, 2002.

39. Batelaan, O.; de Smedt, F. Wetspass: A flexible, GIS based, distributed recharge methodology for regional groundwater modelling. In Impact of Human Activity on Groundwater Dynamics; Gehrels, H., Peters, J., Leibundgut, C., Eds.; International Association of Hydrological Sciences: Wallingford, UK, 2001; pp. 11-17.

40. Park, C.; Seo, J.; Lee, J.; Ha, K.; Koo, M.H. A distributed water balance approach to groundwater recharge estimation for Jeju volcanic island, Korea. Geosci. J. 2014, 18, 193-207. [CrossRef]

41. Batelaan, O.; de Smedt, F. GIS-based recharge estimation by coupling surface-subsurface water balances. J. Hydrol. 2007, 337, 337-355. [CrossRef]

42. Armanuos, A.M.; Negm, A. Assessment of the variations of local parameters of Wetspass model: Case study Nile Delta aquifer. Procedia Eng. 2016, 154, 276-283. [CrossRef]

43. Batelaan, O.; Woldeamlak, S.T. Arcview Interface for WetSpass, Version 13-06-2007; Vrije University Brussels: Brussels, Belgium, 2007.

44. Gao, C. China Groundwater Level Yearbook for Geo-Environmental Monitoring; China Land Press: Beijing, China, 2013; p. 583. (In Chinese)

45. Xu, C.; Singh, V. Review on regional water resources assessment models under stationary and changing climate. Water Resour. Manag. 2004, 18, 591-612. [CrossRef]

46. Tahir, M.E.; Wang, W.; Xu, C.; Zhang, Y. Comparison of methods for estimation of regional actual evapotranspiration in data scarce regions: The Blue Nile region-Eastern Sudan. J. Hydrol. Eng. 2012, 17, 578-589. [CrossRef] 
47. Fiquepron, J.; Garcia, S.; Stenger, A. Land use impact on water quality: Valuing forest services in terms of the water supply sector. J. Environ. Manag. 2013, 126, 13-21. [CrossRef] [PubMed]

48. Zhu, L.; Liu, C.; Li, X. Precipitation infiltration change in Beijing plain in the contex of urbanization. Earth Sci. 2013, 38, 1065-1072. (In Chinese)

49. Shuster, W.; Bonta, J.; Thurston, H.; Warnemuende, E.; Smith, E. Impacts of impervious surface on watershed hydrology: A review. Urban Water J. 2005, 2, 263-275. [CrossRef]

50. Tomer, M.D.; Schilling, K.E. A simple approach to distinguish land-use and climate-change effects on watershed hydrology. J. Hydrol. 2009, 376, 24-33. [CrossRef]

51. Wang, M.; Zhang, D.; Adhityan, A.; Ng, W.J.; Dong, J.; Tan, S.K. Assessing cost-effectiveness of bioretention on stormwater in response to climate change and urbanization for future scenarios. J. Hydrol. 2016, 543, 423-432. [CrossRef]

52. Melki, A.; Abdollahi, K.; Fatahi, R.; Abida, H. Groundwater recharge estimation under semi arid climate: Case of Northern Gafsa watershed, Tunisia. J. Afr. Earth Sci. 2017, 132, 37-46. [CrossRef]

53. Shrestha, S.; Bach, T.V.; Pandey, V.P. Climate change impacts on groundwater resources in Mekong Delta under representative concentration pathways (RCPs) scenarios. Environ. Sci. Policy 2016, 61, 1-13. [CrossRef]

54. Jia, Y.W.; Zhao, H.L.; Niu, C.W.; Jiang, Y.Z.; Hong, G.; Zhi, X.; Zhao, X.L.; Zhao, Z.X. A WebGIS-based system for rainfall-runoff prediction and real-time water resources assessment for Beijing. Comput. Geosci. 2009, 35, 1517-1528. [CrossRef]

55. Minnig, M.; Moeck, C.; Radny, D.; Schirmer, M. Impact of urbanization on groundwater recharge rates in Dübendorf, Switzerland. J. Hydrol. 2017, in press. [CrossRef]

56. Chen, Q.; Wang, L.; Yuan, L. Analysis of urban landscape pattern change in Yanzhou city based on TM/ETM images. Procedia Earth Planet. Sci. 2009, 1, 1191-1197. [CrossRef]

57. Ji, D.; Wen, Y.; Wei, J.; Wu, Z. Relationships between landscape spatial characteristics and surface water quality in the Liu Xi River watershed. Acta Ecol. Sinica 2015, 35, 246-253. (In Chinese)

58. Li, J.; Zhou, Z.X. Coupled analysis on landscape pattern and hydrological processes in Yanhe watershed of China. Sci. Total Environ. 2015, 505, 927-938. [CrossRef] [PubMed]

59. Jia, H.; Ma, H.; Wei, M. Urban wetland planning: A case study in the Beijing central region. Ecol. Complex. 2011, 8, 213-221. [CrossRef] 